\author{
Zbigniew Zioło \\ Uniwersytet Pedagogiczny \\ im. Komisji Edukacji Narodowej \\ w Krakowie
}

\title{
Uwarunkowania rozwoju przedsiębiorczości w warunkach kryzysu gospodarczego
}

\author{
The conditions for entrepreneurship development during an economic crisis
}

\begin{abstract}
Streszczenie
W pracy główną uwagę zwrócono na: określenie miejsca przedsiębiorczości w strukturze gospodarki rynkowej, przejawy wpływu kryzysu na gospodarkę narodową, proces upadłości przedsiębiorstw, wpływ sytuacji kryzysowej na rynek pracy, zachowania wybranych sektorów gospodarki w nasilającej się sytuacji kryzysowej, sytuację finansową przedsiębiorstw, uwarunkowania instytucjonalne rozwoju działalności gospodarczej i procesy migracji.
\end{abstract}

\begin{abstract}
The following paper focuses mainly on determining the characteristic role of entrepreneurship in the structure of market economy, the impact of recession symptoms on national economy, bankruptcy processes of companies, the impact of recession on the labour market, performance of selected sectors of economy in a deepening recessions, the financial condition of companies, institutional factors of economic growth and migration processes.
\end{abstract}

Słowa kluczowe: gospodarka narodowa; kryzys; migracje; przedsiębiorczość

Key words: national economy; recession; migrations; entrepreneurship

\section{Wprowadzenie}

Nasilająca się sytuacja kryzysowa stwarza odmienne możliwości prowadzenia działalności gospodarczej zarówno dla światowych koncernów, dużych i średnich przedsiębiorstw, jak i dla małych firm zwykle o funkcjach lokalnych. Dlatego szczególnie ważnym zagadnieniem jest coraz precyzyjniejsze poznawanie mechanizmu funkcjonowania gospodarki oraz doskonalenie umiejętności ciągłego poszukiwania przez przedsiębiorstwo swojego miejsca w różnych strukturach zmieniającego się rynku. Znaczącą rolę w tym zakresie odgrywa wykształcanie postaw przedsiębiorczych, które umożliwią zdobywanie umiejętności wykorzystania wiedzy teoretycznej i praktycznej dla osiągania sukcesów, oraz rozwijanie działalności gospodarczej. Na tym tle możemy przyjąć, że przedsiębiorczość przejawia się w umiejętności wykorzystania wiedzy dla zdobycia określonych zasobów kapitałowych i finansowych.

Po przyjęciu powyższych założeń celem niniejszych rozważań jest określenie uwarunkowań dla rozwoju przedsiębiorczości oraz ich zmian w latach kryzysu gospodarczego, a na tym tle zarysowanie tendencji przemian gospodarki krajowej i zachowań podmiotów gospodarczych. 
Problematyka genezy, przebiegu i skutków kryzysu gospodarczego oraz możliwości wyjścia z niego jest przedmiotem zainteresowań naukowców z wielu dyscyplin naukowych, a także elit politycznych i społeczeństwa, które w największym stopniu odczuwa negatywne konsekwencje kryzysu. Z pozycji różnych szkół ekonomicznych określane są jego przyczyny oraz prezentowane są różne możliwości ograniczania jego negatywnych skutków, a następnie poszukiwania najefektywniejszych dróg wychodzenia z niego. Problematyka ta znalazła się także w kręgu zainteresowań geografii przemysłu i wydaje się, że należy ją rozwijać na gruncie edukacji przedsiębiorczości.

\section{Miejsce przedsiębiorstwa w strukturze gospodarki rynkowej}

Zachowanie przedsiębiorstwa w gospodarce nawiązuje do reguł mikroekonomicznych, gdyż celem jego działalności jest wypracowanie maksymalnego zysku. W strukturze przedsiębiorstwa podejmowane są samodzielne decyzje, podporządkowane własnym interesom, które równocześnie związane są z ponoszeniem przez nie określonego ryzyka. Przedsiębiorstwo funkcjonuje i rozwija się w określonym otoczeniu innych przedsiębiorstw, instytucji, uwarunkowań rynkowych, społecznych, które wynikają z określonych celów krajowej i międzynarodowej polityki gospodarczej (Zioło, 1988, 1994; Rachwał, 2001). Układ ten kształtuje się zgodnie z regułami makroekonomicznymi, które przy wykorzystaniu odpowiednich instrumentów ekonomicznych zwracają główną uwagę na podnoszenie efektywności gospodarki narodowej. W tej sytuacji w procesie kształtowania gospodarki zaznaczają się obiektywne konflikty występujące między dążeniami przedsiębiorstwa a dążeniami gospodarki narodowej ${ }^{1}$.

Przedsiębiorstwo w strukturze gospodarki jest jednym z ważnych elementów, które oddziałują na otoczenie, jednak otoczenie także w istotnym stopniu wpływa na jego możliwości rozwojowe (m.in. Misztal, Zioło, 1998; Zioło, Rachwał, 2009, 2010, 2011a, 2011b). W niniejszych rozważaniach ograniczymy się do wybranych cech wpływających w istotnym stopniu na uwarunkowania funkcjonowania przedsiębiorstwa w warunkach kryzysu gospodarczego (ryc. 1).

Kształtowanie działalności produkcyjnej bądź usługowej w podstawowym stopniu uzależnione jest od rozmiarów rynku, który tworzą: gospodarstwa domowe, inne przedsiębiorstwa odbierające lub dostarczające surowce, półfabrykaty czy gotowe elementy służące do montażu, a także różnego rodzaju instytucje publiczne i in. Rynek ten w zależności od potencjału ekonomicznego przedsiębiorstwa może mieć zasięg lokalny, regionalny, krajowy lub międzynarodowy.

$\mathrm{Na}$ rozmiary chłonności rynku w zasadniczym stopniu wpływają gospodarstwa domowe, które stwarzają popyt na oferowane produkty. Siła oddziaływania gospodarstw na rynek zależy od wielkości środków finansowych płynących do nich z różnorodnych źródeł zasilania. Źródła te reprezentują głównie: dochody z pracy ludności aktywnej zawodowo, niezarobkowe źródła utrzymania, dochody z pracy za granicą, dochody z pracy w szarej strefie, zgromadzone wcześniej własne oszczędności oraz możliwości kredytowe oferowane przez instytucje finansowe.

Dla przedsiębiorstwa przy podejmowaniu działalności gospodarczej (produkcyjnej, usługowej) ważnym zagadnieniem są źródła zasilania finansowego, które reprezentują instytucje finansowe (banki, giełda), możliwości sprzedaży zbędnych zasobów (np. terenów, budynków, budowli), budżet państwa czy własne zasoby zgromadzone w bankach. W tym zakresie

\footnotetext{
${ }^{1}$ Przejawia się to m.in. w tym, że przedsiębiorstwa chciałyby płacić do budżetu państwa jak najmniejsze kwoty podatków i różnych opłat, a budżet państwa chciałby pozyskać jak największe dochody płynące z działalności przedsiębiorstw. Podobnie celem przedsiębiorstw jest racjonalizacja zatrudnienia, a celem gospodarki narodowej jest wzrost rynku pracy, dążenie do ograniczania bezrobocia i zmniejszania związanej z nim pomocy budżetowej.
} 
Ryc. 1. Miejsce przedsiębiorstwa w strukturze gospodarki rynkowej

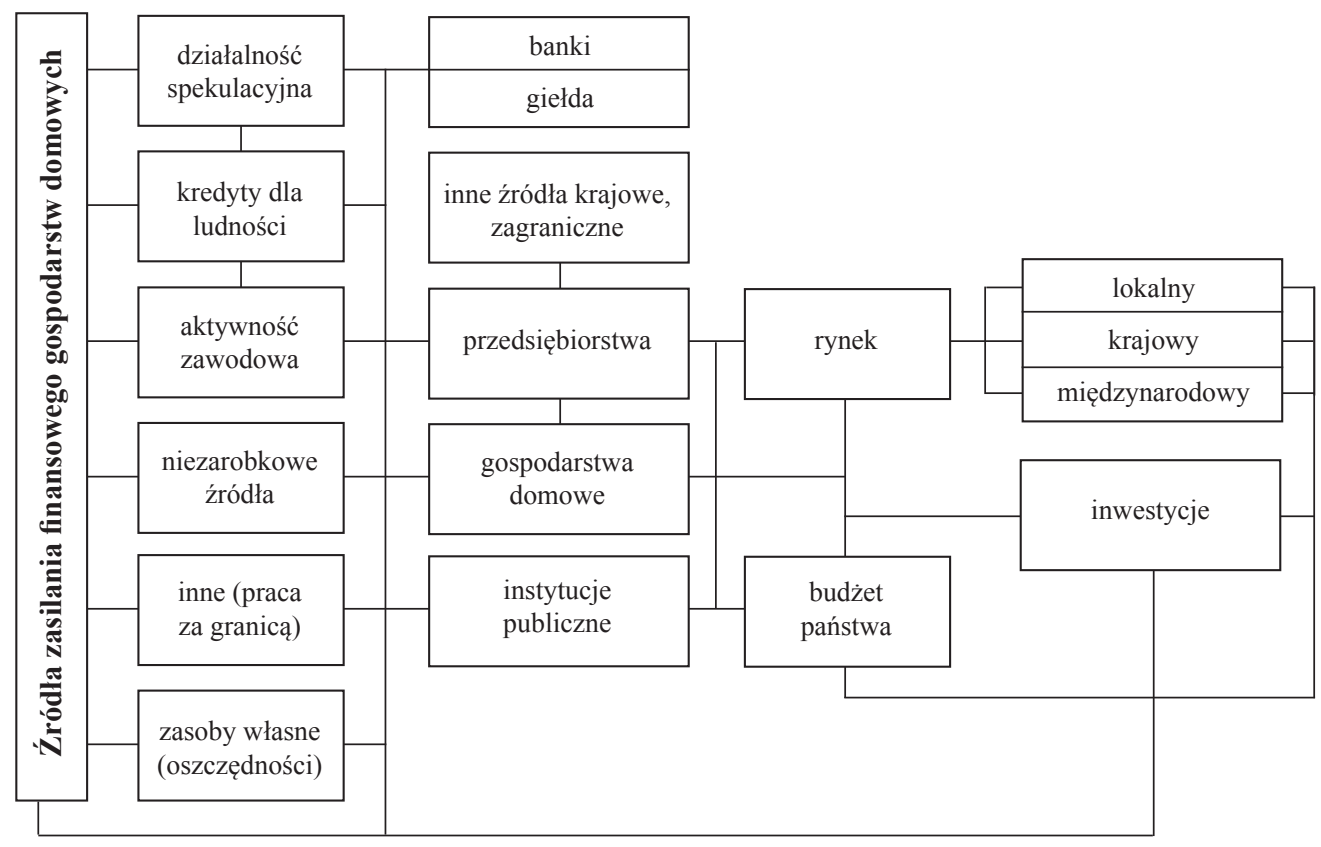

Źródło: opracowanie własne.

szczególnie istotne miejsce w otoczeniu przedsiębiorstwa zajmuje budżet państwa, którego rozmiary zależą od wartości opłat przedsiębiorstw (wynikających z wielkości produkcji), wielkości zasilania finansowego gospodarstw domowych, zgromadzonych zasobów oraz chłonności rynku, wpływającego na rozmiary różnego rodzaju podatków pośrednich (np. VAT). Rozmiary budżetu umożliwiają w znacznym stopniu: pobudzanie działalności gospodarczej przedsiębiorstw, instytucji publicznych i finansowych, zagwarantowanie odpowiedniego poziomu zasilania finansowego gospodarstw domowych (słabych ekonomicznie, zasiłki dla bezrobotnych, pomoc dla najuboższych i in.), a także aktywizację rynku zbytu produktów (np. dotacje do zakupu nowych samochodów czy zmniejszenia wielkości podatków pośrednich) lub aktywizację rynku pracy.

Znaczącą rolę odgrywają inwestycje produkcyjne i infrastrukturalne prowadzone przez przedsiębiorstwa i instytucje. Dzięki nim powstają nowe miejsca pracy, które zwiększają stopień aktywizacji zasobów pracy, ograniczają bezrobocie i zmniejszają konieczność wydatków na zasiłki dla ludności, a w konsekwencji wpływają na podnoszenie jakości życia ludności.

W sytuacji kryzysowej w zarysowanym układzie zaznaczają się pewne zakłócenia powiązań funkcjonalnych zachodzących między wyróżnionymi elementami strukturalnymi gospodarki, w tym relacji przedsiębiorstwa z elementami jego otoczenia. Głównym czynnikiem zachwiania wykształconych relacji funkcjonalnych są najczęściej ograniczenia wielkości przepływów strumieni kapitałowo-finansowych i produktów lub zmiana kierunków ich przepływu wywołanych przez decyzje polityki społeczno-gospodarczej czy polityki zagranicznej (ryc. 2). Zmniejszanie zasobów finansowych społeczeństwa wpływa na ograniczanie chłonności rynku. Powoduje to zmniejszanie zapotrzebowania na wyroby i usługi, a w konsekwencji ograniczanie produkcji, ograniczanie zasilania finansowego gospodarstw domowych i budżetu, ograniczanie działalności kredytowej, trudności w realizacji przepływów finansowych między podmio- 
Ryc. 2. Przyczyny i konsekwencje sytuacji kryzysowej dla rozwoju przedsiębiorczości

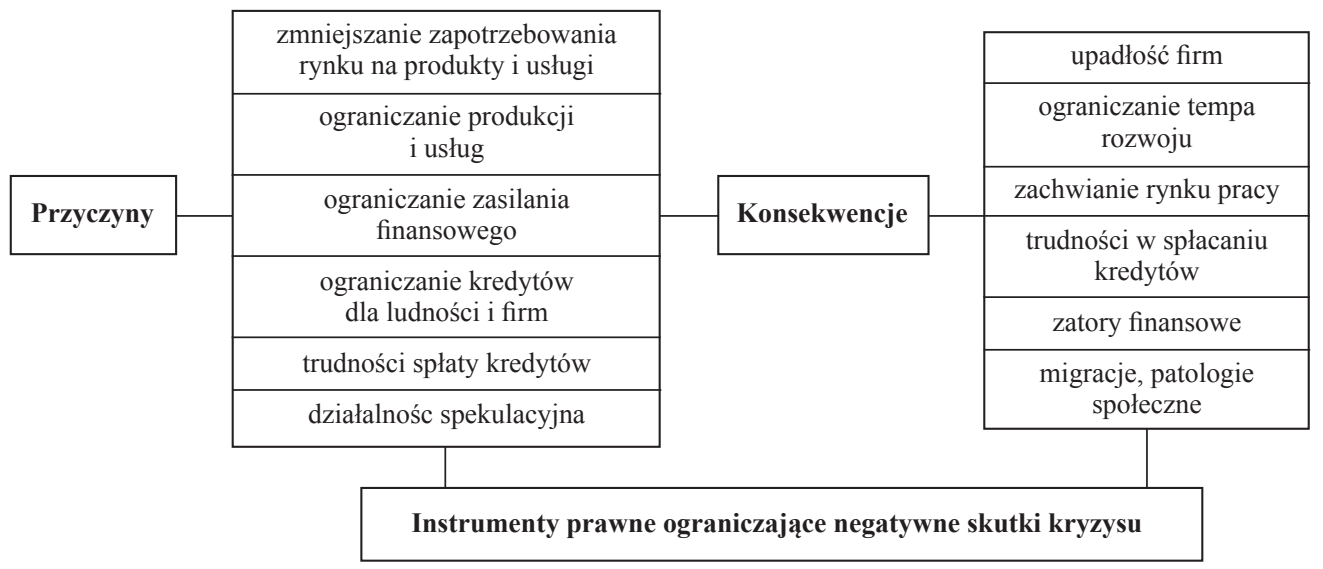

Źródło: opracowanie własne.

tami gospodarczymi (zatory płatnicze), aktywizację działalności spekulacyjnej, a także radykalizację zachowań społecznych.

W konsekwencji prowadzi to do upadłości firm, a następnie do ograniczania tempa wzrostu gospodarczego, kurczenia się rynku zbytu gotowych produktów i oferowanych usług, zmniejszania poziomu zatrudnienia, recesji na rynku pracy, nasilania się bezrobocia. Ograniczenia finansowe wynikające $\mathrm{z}$ tego tytułu sprawiają trudności w spłacaniu kredytów, uaktywniają migrację zarobkową ludności, nasilają drenaż najbardziej wartościowych zasobów pracy oraz wpływają na rozwój zjawisk patologii społecznej.

Sytuacja ta wpływa na zmianę istniejących i pojawianie się nowych instrumentów prawnych mających na celu ograniczanie negatywnych skutków kryzysu. Trudności w tym zakresie związane są głównie z malejącymi wpływami finansowymi do budżetu, a równocześnie rosnącymi potrzebami budżetowymi państwa, które są niezbędne dla ograniczania negatywnych zjawisk kryzysowych. Jedynym wyjściem w takiej sytuacji jest zaciąganie przez państwo nowych kredytów oraz nasilanie systemu fiskalnego prowadzącego do zwiększania obciążeń finansowych przedsiębiorstw i ludności. Sytuację tego typu mogą pogarszać braki w zakresie umiejętności prowadzenia dialogu społecznego oraz rosnące żądania, często wynikające z pojawiania się działań populistycznych pewnych grup ${ }^{2}$.

\section{Przejawy wpływu kryzysu na gospodarkę}

Wyrazem wzrostu potencjału ekonomicznego, a także zmienności warunków rozwoju przedsiębiorczości, są wahania dynamiki produktu krajowego brutto $(\mathrm{PKB})^{3}$. W latach przedkryzy-

${ }^{2}$ Ilustracją tego jest niezadowolenie mieszkańców Grecji oraz Hiszpanii, a także ucieczka przedsiębiorstw do tzw. rajów podatkowych i migracja najbogatszych obywateli do krajów o niższych stopach podatkowych. Na przykład w wyniku kryzysu najbogatsi Francuzi zostali obciążeni 75-procentowym podatkiem od dochodów, stąd część z nich zmieniła miejsce zamieszkania na kraje o niższych stopach podatkowych, takich jak Rosja, w której wynoszą one tylko 13\%.

3 „PKB obrazuje końcowy rezultat działalności wszystkich podmiotów gospodarki narodowej; równa się sumie wartości dodanej brutto wszystkich sektorów własności albo sektorów instytucjonalnych lub sumie dochodów wartości dodanej brutto wszystkich sekcji, działów powiększonej o podatki od produktów i pomniejszonej o dotacje do produktów" (GUS, 2010: 736). 
sowych gospodarka krajowa na tle krajów europejskich odznaczała się znaczącym wzrostem, co ilustruje stosunkowo wysoka dynamika PKB, która systematycznie rosła z 103,9 w 2003 r. do 106,8 w 2007 r., gdy w tym czasie kraje dominujące w światowej gospodarce odznaczały się niższym tempem wzrostu (tab. 1). Dynamika wzrostu PKB Stanów Zjednoczonych zmniejszała się z 103,5 do 101,9, a Niemiec zwiększała się z 99,8 do 103,7. Intensywniejszym wzrostem charakteryzowały się kraje grupy BRIC (Brazylia, Rosja, Indie, Chiny). W analizowanym okresie dynamika wzrostu PKB gospodarki Brazylii wzrosła od 101,1 do106,1, Chin od 110,0 do114,2, Indii od 108,4 do 109,6, a Rosji od 107,3 do 108,2 i państwa te znacznie przewyższały wzrost dynamiki światowej, która charakteryzowała się wzrostem od 102,7 do 104,1. Podkreśla to wolniejsze tempo wzrostu dominujących gospodarek światowych i znacznie intensywniejszy wzrost krajów BRIC, które wyrastają na nowe światowe bieguny wzrostu ekonomicznego.

W latach kryzysu nastąpił znaczny spadek dynamiki PKB w gospodarce światowej z 104,0 w 2007 r. do 98,0 w 2009 r. W 2009 r. spośród krajów UE tylko Polska odznaczała się wzrostem PKB, do 101,7, natomiast w pozostałych krajach występowała recesja, a dynamika ich gospodarek znacznie spadła i wahała się od 98,3\% (Cypr) do (82,3\% (Łotwa). W tymże roku dynamika gospodarki dominujących krajów na świecie zmniejszyła się: we Francji do 97,3\%, w Stanach Zjednoczonych do 96,5\%, w Wielkiej Brytanii do 95,1\% i w Niemczech do 94,9\%. Odmiennymi tendencjami charakteryzowały się gospodarki krajów BRIC. Dynamika gospodarki chińskiej nieco spadła, ze 114,2 do 109,1, gospodarki indyjskiej ze 109,6 do 107,7, brazylijskiej do 99,8 i rosyjskiej do 92,1. Podkreśla to bardzo duże zróżnicowanie przestrzenne recesji gospodarczej, która w największym stopniu objęła Stany Zjednoczone i kraje europejskie, a tylko osłabiła gospodarkę Chin i Indii.

W gospodarce polskiej zaznaczyło się w tym czasie różnicowane tempo wzrostu (tab. 2). W latach 2008-2012 wyróżniają się cztery okresy odznaczające się różnymi tendencjami dynamiki PKB. Od pierwszego kwartału 2008 r. do pierwszego kwartału 2009 r. następował systematyczny spadek dynamiki PKB z 6,3 do 0,4, po czym do czwartego kwartału 2009 r.

Tab. 1. Dynamika PKB Polski na tle dominujących gospodarek światowych

\begin{tabular}{|l|c|c|c|c|c|c|c|c|}
\hline \multicolumn{1}{|c|}{ Kraje } & $\mathbf{2 0 0 3}$ & $\mathbf{2 0 0 4}$ & $\mathbf{2 0 0 5}$ & $\mathbf{2 0 0 6}$ & $\mathbf{2 0 0 7}$ & $\mathbf{2 0 0 8}$ & $\mathbf{2 0 0 9}$ & $\mathbf{2 0 1 0}$ \\
\hline Polska & 103,9 & 105,3 & 103,6 & 106,2 & 106,8 & 105,1 & 101,7 & 103,9 \\
\hline Stany Zjednoczone & 102,5 & 103,5 & 103,1 & 102,7 & 101,9 & 99,7 & 96,5 & 103,0 \\
\hline W. Brytania & 103,0 & 103,0 & 102,2 & 102,7 & 102,7 & 99,9 & 95,1 & 101,4 \\
\hline Francja & 101,1 & 102,5 & 101,8 & 102,5 & 102,3 & 99,9 & 97,3 & 101,5 \\
\hline Niemcy & 99,8 & 101,2 & 100,7 & 103,7 & 103,3 & 101,1 & 94,9 & 103,7 \\
\hline Chiny & 110,0 & 110,1 & 111,3 & 112,7 & 114,2 & 109,6 & 109,1 & 110,3 \\
\hline Indie & 108,4 & 108,3 & 109,3 & 109,4 & 109,6 & 105,1 & 107,7 & 109,7 \\
\hline Brazylia & 101,1 & 105,7 & 103,2 & 104,0 & 106,1 & 105,1 & 99,8 & 107,5 \\
\hline Rosja & 107,3 & 107,2 & 106,4 & 108,2 & 108,1 & 105,2 & 92,1 & 104,0 \\
\hline Świat & 102,7 & 104,1 & 103,6 & 104,1 & 104,0 & 101,7 & 98,0 & \\
\hline
\end{tabular}

Źródło: opracowanie własne na podstawie roczników statystycznych GUS z lat 2007-2011. 
Tab. 2., ryc. 3. Dynamika polskiego PKB w latach 2008-2012

\begin{tabular}{|c|c|c|}
\hline Rok & Kwartal & Dynamika \\
\hline 2008 & I & 6,3 \\
\cline { 2 - 3 } & II & 6,1 \\
\cline { 2 - 3 } & III & 5,2 \\
\cline { 2 - 3 } & IV & 3,2 \\
\hline 2009 & I & 0,4 \\
\cline { 2 - 3 } & II & 1,0 \\
\cline { 2 - 3 } & III & 1,6 \\
\cline { 2 - 3 } & IV & 3,2 \\
\hline 2010 & I & 2,7 \\
\cline { 2 - 3 } & II & 3,7 \\
\cline { 2 - 3 } & III & 4,2 \\
\cline { 2 - 3 } & IV & 4,7 \\
\hline 2011 & I & 4,6 \\
\cline { 2 - 3 } & II & 4,2 \\
\cline { 2 - 3 } & III & 4,2 \\
\cline { 2 - 3 } & IV & 4,3 \\
\hline 2012 & I & 3,6 \\
\cline { 2 - 3 } & II & 2,3 \\
\hline & III & 1,4 \\
\hline & IV & 0,7 \\
\hline
\end{tabular}

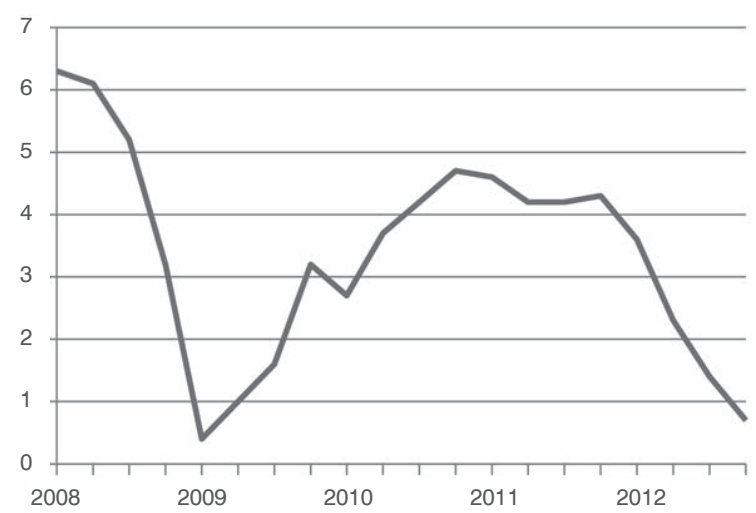

Źródło: Bank Danych Lokalnych GUS.

wzrósł do 4,7 i na zbliżonym poziomie utrzymywał się do czwartego kwartału 2011 r., a następnie nastąpiła ponowna recesja do 0,7 w czwartym kwartale $2012 \mathrm{r}$. Załamania te w pewnym stopniu związane są z sezonowością działalności niektórych przedsiębiorstw, zwłaszcza budowlanych, dla których miesiące zimowe nie są korzystne, a także z kurczącymi się wydatkami finansowymi społeczeństwa wobec wizji zbliżającego się kryzysu.

\section{Upadłość przedsiębiorstw}

W zasadniczym stopniu na osłabienie dynamiki rozwoju gospodarczego wpływa upadek krajowych firm. W latach 2004-2012 proces upadłości przebiegał z różnym nasileniem i objął łącznie 6,5 tys. firm (tab. 3). Początkowo w warunkach rozwoju gospodarczego (2004-2008) liczba upadających firm systematycznie zmniejszała się z 1163 do 425 . Dokonywała się wówczas pewna selekcja, obejmująca firmy bez silnych podstaw ekonomicznych, których lokalizacje nie zawsze były racjonalne, oraz firmy powstałe jeszcze w latach gospodarki centralnie sterowanej, które miały trudności w dostosowaniu się do nowych warunków wdrażania gospodarki rynkowej. Ponowny wzrost upadłości firm do liczby 877 w 2012 r. nastąpił w wyniku nasilającego się kryzysu, który stwarzał niekorzystne uwarunkowania związane głównie z ograniczaniem płynności finansowej oraz spadającym popytem, wywołanym w znacznym stopniu zubożeniem społeczeństwa i ograniczeniem eksportu. 
Tab. 3., ryc. 4. Liczba upadłych firm w Polsce w latach 2004-2012

\begin{tabular}{|c|c|c|}
\hline Rok & $\begin{array}{c}\text { Liczba } \\
\text { upadłych } \\
\text { firm }\end{array}$ & $\begin{array}{c}\text { Dynamika } \\
\text { w stosunku } \\
\text { do roku } \\
\text { poprzedniego }\end{array}$ \\
\hline 2004 & 1163 & 100,0 \\
\hline 2005 & 861 & 74,0 \\
\hline 2006 & 648 & 75,3 \\
\hline 2007 & 480 & 74,1 \\
\hline 2008 & 425 & 88,5 \\
\hline 2009 & 673 & 158,4 \\
\hline 2010 & 691 & 102,7 \\
\hline 2011 & 730 & 105,6 \\
\hline 2012 & 877 & 120,1 \\
\hline
\end{tabular}

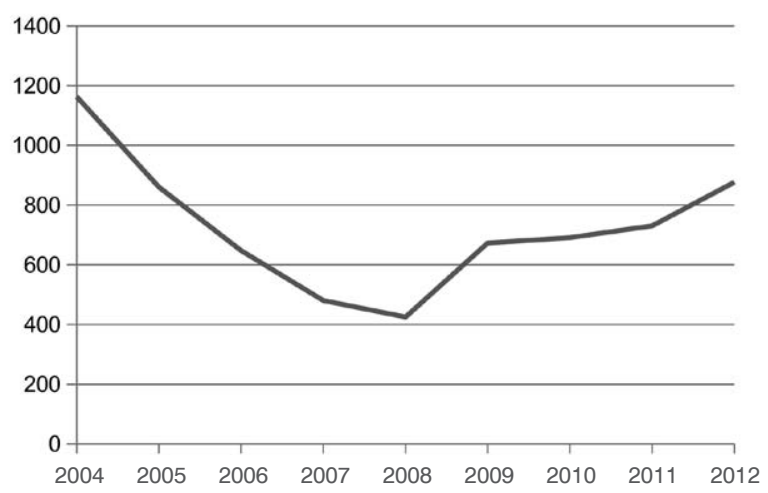

Źródło: opracowanie własne na podstawie danych GUS z lat 2004-2012.

W okresie nieznacznego ożywienia gospodarczego w dynamice upadłości firm uwidaczniły się wyraźne wahania. W 2011 r. od stycznia do maja można było zaobserwować w miarę wyrównane tendencje $\mathrm{w}$ upadłości firm, a następnie nasilenie się tego procesu zaznaczyło się od czerwca do lipca, po czym w kolejnych miesiącach do końca grudnia nastąpiło jego osłabienie (tab. 4). Upadło wówczas wiele firm, które nie mogły znaleźć swojego miejsca w warunkach ponownego nasilenia się sytuacji kryzysowej. W 2012 r. już silniej zaznaczył się wpływ kryzysu gospodarczego, który pociągnął za sobą nasilenie zjawiska upadłości firm. Likwidowały swoją działalność głównie małe podmioty gospodarcze związane z handlem detalicznym, które nie były w stanie sprostać konkurencji dużych marketów. Ich liczba zmniejszyła się z 128,6 tys. w 2009 r. do 110,0 w roku 2011. Upadały także firmy budowlane, co związane było z ograniczeniami działalności inwestycyjnej przedsiębiorstw, zmniejszaniem się popytu na nowe mieszkania oraz zatorami płatniczymi wynikającymi głównie z budowy autostrad. Wielu głównych wykonawców nie było bowiem w stanie wypłacać należnych kwot za wykonane prace przez mniejsze przedsiębiorstwa i przedsiębiorstwa słabsze kapitałowo.

Proces upadłości z różnym nasileniem zaznaczył się w krajowej przestrzeni gospodarczej, czego wyrazem jest znaczne zmniejszenie liczby firm na terenie poszczególnych województw (tab. 5). W 2011 r., od stycznia do października, najwięcej firm upadło na terenie województwa mazowieckiego - 135 - a w tym samym okresie w 2012 r. liczba upadłości zwiększyła się do 163, czyli do 120,7\%. Upadłości te obejmowały odpowiednio 21,5\% i 21,1\% ogólnej liczby upadłych firm na terenie kraju. Następnie znaczący wzrost upadłości wystąpił na terenach najbardziej rozwiniętych województw: śląskiego, gdzie liczba upadłych firm zwiększyła się z 78 do 83, a także wielkopolskiego i dolnośląskiego. Łącznie obejmowały one odpowiednio $33,8 \%$ i 33,1\% upadających firm na terenie kraju.

Najsilniejsza dynamika upadłości zaznaczyła się na terenach najsłabiej rozwiniętych województw, podlaskiego, gdzie liczba upadających firm zwiększyła się ponad trzykrotnie (z 6 do 21), świętokrzyskiego (ponaddwukrotnie), lubelskiego (blisko dwukrotnie) i kujawsko-pomorskiego. Jedynie na terenie województwa łódzkiego zaznaczyło się osłabienie tempa upadłości firm, a ich liczba zmniejszyła się z 32 do 30 . W przestrzeni krajowej proces upadłości w obu okresach 
Tab. 4. Firmy ogłaszające upadłość w Polsce w latach 2011-2012

\begin{tabular}{|c|c|c|c|c|}
\hline \multirow{2}{*}{ Rok } & \multirow{2}{*}{ Miesiące } & \multirow{2}{*}{$\begin{array}{c}\text { Liczba firm oglaszających } \\
\text { upadlość }\end{array}$} & \multicolumn{2}{|r|}{ Dynamika } \\
\hline & & & styczeń $=100$ & miesiąc poprzedni $=100$ \\
\hline \multirow{12}{*}{2011} & $\mathrm{I}$ & 64 & 100,0 & 100,0 \\
\hline & II & 59 & 92,2 & 92,2 \\
\hline & III & 70 & 109,4 & 118,6 \\
\hline & IV & 62 & 96,9 & 88,6 \\
\hline & $\mathrm{V}$ & 63 & 98,4 & 101,6 \\
\hline & VI & 57 & 89,1 & 90,5 \\
\hline & VII & 76 & 118,8 & 133,3 \\
\hline & VIII & 56 & 87,5 & 73,7 \\
\hline & IX & 64 & 100,0 & 114,3 \\
\hline & $\mathrm{X}$ & 56 & 87,5 & 87,5 \\
\hline & $\mathrm{XI}$ & 62 & 96,9 & 110,7 \\
\hline & XII & 41 & 64,1 & 66,1 \\
\hline \multirow{12}{*}{2012} & $\mathrm{I}$ & 66 & 103,1 & 161,0 \\
\hline & II & 71 & 110,9 & 107,6 \\
\hline & III & 74 & 115,6 & 104,2 \\
\hline & IV & 64 & 100,0 & 86,5 \\
\hline & $\mathrm{V}$ & 82 & 128,1 & 128,1 \\
\hline & VI & 68 & 106,3 & 82,9 \\
\hline & VII & 70 & 109,4 & 102,9 \\
\hline & VIII & 73 & 114,1 & 104,3 \\
\hline & IX & 52 & 81,3 & 71,2 \\
\hline & $X$ & 91 & 142,2 & 175,0 \\
\hline & XI & 86 & 134,4 & 94,5 \\
\hline & XII & 80 & 125,0 & 93,0 \\
\hline
\end{tabular}

Ryc. 5. Liczba firm ogłaszających upadłość w Polsce

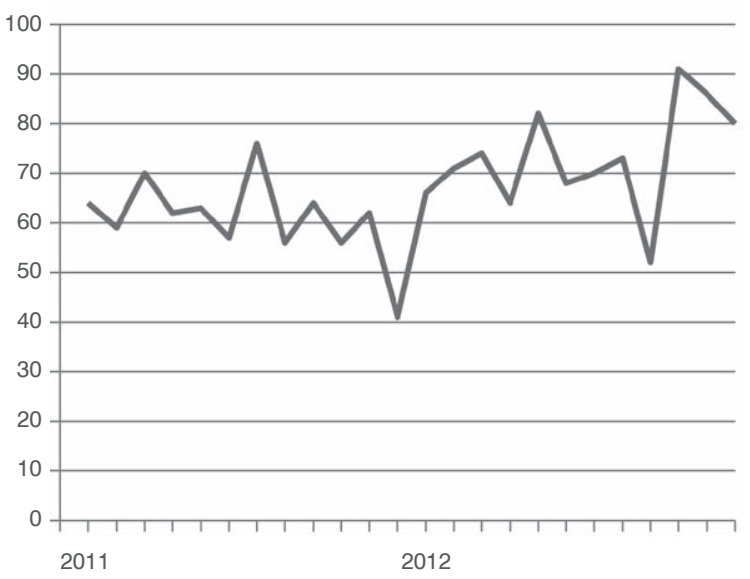

Źródło: Reda-Jakima (2013: B3). 
Tab. 5. Upadłość polskich firm wg województw

\begin{tabular}{|l|c|c|c|}
\hline \multirow{2}{*}{ Województwa } & \multicolumn{2}{|c|}{ Liczba upadłości w okresie I-X } & \multirow{2}{*}{ Dynamika 2011-2012 } \\
\cline { 2 - 4 } & $\mathbf{2 0 1 1}$ & $\mathbf{2 0 1 2}$ & 120,7 \\
\hline Mazowieckie & 135 & 163 & 114,3 \\
\hline Dolnośląskie & 77 & 88 & 149,1 \\
\hline Wielkopolskie & 57 & 85 & 106,4 \\
\hline Śląskie & 78 & 83 & 118,2 \\
\hline Zachodniopomorskie & 55 & 65 & 105,6 \\
\hline Małopolskie & 54 & 57 & 122,6 \\
\hline Pomorskie & 31 & 38 & 138,5 \\
\hline Kujawsko-pomorskie & 26 & 36 & 93,8 \\
\hline Lódzkie & 32 & 30 & 193,3 \\
\hline Lubelskie & 15 & 29 & 122,2 \\
\hline Warmińsko-mazurskie & 18 & 22 & 105,0 \\
\hline Podkarpackie & 20 & 21 & 350,0 \\
\hline Podlaskie & 6 & 21 & 200,0 \\
\hline Świętokrzyskie & 6 & 12 & 120,0 \\
\hline Opolskie & 10 & 12 & 157,1 \\
\hline Lubuskie & 7 & 11 & \\
\hline
\end{tabular}

Źródło: Więcław (2010).

przebiegał z bardzo zbliżonym nasileniem, co ilustruje wysoka wartość współczynnika korelacji między upadłościami w pierwszym i drugim okresie, która wyniosła 0,984.

Relatywnie najmocniej upadłości zaznaczyły się na terenach województw słabiej rozwiniętych, natomiast najwyższy spadek potencjału w strukturze krajowej wystąpił na obszarach województw stojących na najwyższym poziomie rozwoju. W układach regionalnych w najpoważniejszym stopniu na upadłość firm wpływały zatory płatnicze, które szczególnie silnie zaznaczyły się w budownictwie, handlu, działalności finansowej i telekomunikacji; ograniczanie chłonności rynku, które najmocniej zaznaczyły się w województwach słabiej rozwiniętych, a także mało spójny system instrumentów prawnych i słabość organów państwowych ${ }^{4}$.

\section{Sytuacja kryzysowa na rynku pracy}

W konsekwencji sytuacji kryzysowej prowadzącej do ograniczenia działalności i upadku firm nastąpiły znaczne ograniczenia rozmiarów rynku pracy, czego wyrazem jest wahająca się i stosunkowo wysoka stopa bezrobocia (tab. 6). W latach 2002-2008 systematycznie spadała ona z 19,5 do 9,1 a następnie w latach kryzysu na koniec września 2012 r. wzrosła do 12,4 i, według prognoz, będzie nadal wzrastać.

\footnotetext{
${ }^{4}$ Ilustracją tego może być np. upadek poznańskiej firmy informatycznej „Bestcom”. Po siedmiu latach śledztwa i licznych aresztowaniach zniszczono dochodową firmę (podobnie jak wcześniej firmę R. Kluski), w wyniku czego straciło pracę ponad 75 osób. Firma ta miała ok. $120 \mathrm{mln}$ rocznego obrotu oraz podpisane umowy na otwarcie około 200 sklepów. Później, w wyniku procesu, przedsiębiorcy zostali przez sąd uniewinnieni. Należy wnosić, że podobne inne przykłady podważają wśród społeczeństwa autorytet kraju jako państwa prawa (Wybranowski, 2012, 2013).
} 
Tab. 6., ryc. 6. Zmiany stopy bezrobocia w Polsce w latach 2002-2012

\begin{tabular}{|c|c|}
\hline Rok & $\begin{array}{c}\text { Stopa } \\
\text { bezrobocia }\end{array}$ \\
\hline 2002 & 19,5 \\
\hline 2003 & 19,5 \\
\hline 2004 & 19,1 \\
\hline 2005 & 17,7 \\
\hline 2006 & 15,5 \\
\hline 2007 & 11,9 \\
\hline 2008 & 9,1 \\
\hline 2009 & 10,8 \\
\hline 2010 & 11,4 \\
\hline 2011 & 11,8 \\
\hline 2012 & 12,4 \\
\hline
\end{tabular}

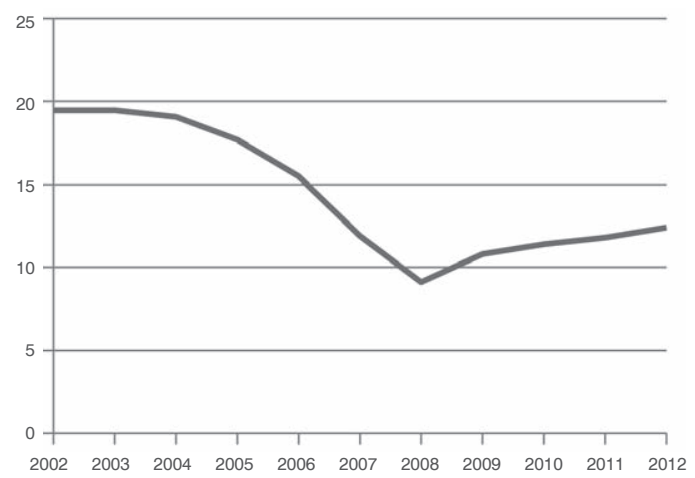

Źródło: opracowanie własne na podstawie roczników statystycznych GUS z lat 2002-2012.

Bezrobocie jest bardzo szybko reagującym zjawiskiem na zmieniające się warunki rozwoju (tab. 7). Od października 2011 r. do stycznia 2012 r. stopa bezrobocia systematycznie wzrastała z 11,8 do 13,2 i na tak wysokim poziomie utrzymywała się do marca 2012 r. W pewnym stopniu na ten stan wpłynęła sezonowa działalność wielu przedsiębiorstw. W następnych miesiącach letnich do sierpnia zaznaczył się spadek stopy bezrobocia do 12,3 i na zbliżonym poziomie stopa bezrobocia utrzymywała się do października 2012 r.

Tab. 7., ryc. 7. Zmiany stopy bezrobocia w Polsce od sierpnia 2011 do października 2012 r.

\begin{tabular}{|c|c|c|}
\hline \multirow{4}{*}{ Rok } & Miesiące & $\begin{array}{c}\text { Stopa } \\
\text { bezrobocia }\end{array}$ \\
\hline \multirow{4}{*}{2011} & VIII & 11,8 \\
\cline { 2 - 3 } & IX & 11,8 \\
\cline { 2 - 3 } & $\mathrm{X}$ & 11,8 \\
\cline { 2 - 3 } & $\mathrm{XI}$ & 12,1 \\
\cline { 2 - 3 } & $\mathrm{XII}$ & 12,5 \\
\hline \multirow{7}{*}{ I } & $\mathrm{I}$ & 13,2 \\
\cline { 2 - 3 } & $\mathrm{II}$ & 13,4 \\
\cline { 2 - 3 } & $\mathrm{III}$ & 13,3 \\
\cline { 2 - 3 } & $\mathrm{IV}$ & 12,9 \\
\cline { 2 - 3 } & $\mathrm{V}$ & 12,6 \\
\cline { 2 - 3 } & $\mathrm{VI}$ & 12,3 \\
\cline { 2 - 3 } & $\mathrm{VII}$ & 12,3 \\
\cline { 2 - 3 } & $\mathrm{VIII}$ & 12,4 \\
\cline { 2 - 3 } & $\mathrm{IX}$ & 12,4 \\
\cline { 2 - 3 } & $\mathrm{X}$ & 12,5 \\
\hline
\end{tabular}

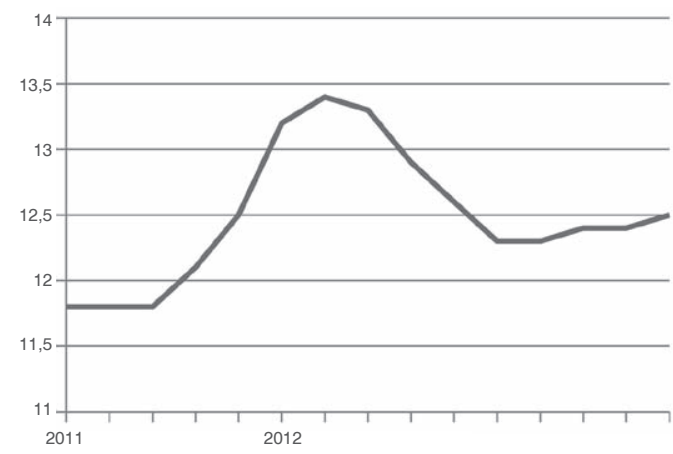

Źródło: GUS (2013a). 
W przestrzeni krajowej proces ten charakteryzuje się dużą zmiennością. Ilustruje to wartość stopy bezrobocia, która na terenach poszczególnych województw wahała się od 9,1 do 19,5, oraz liczba bezrobotnych przypadających na jedną ofertę pracy, wahająca się od 30 do 113 (tab. 8).

Najniższymi wskaźnikami bezrobocia odznaczały się województwa: wielkopolskie $(9,1)$, mazowieckie $(10,2)$, śląskie $(10,4)$, małopolskie $(10,6)$, które na swoim obszarze mają wykształcone dominujące w kraju metropolie. Natomiast najwyższymi wartościami charakteryzują się województwa wschodniego pogranicza (warmińsko-mazurskie - 19,5 i podkarpackie 15,1), województwa: lubuskie $(15,1)$ i kujawsko-pomorskie $(16,7)$, które jeszcze nie wykształciły na swoim obszarze znaczących metropolii a także województwo zachodniopomorskie $(16,7)$, położone z dala od stolicy, które nie wykorzystuje jeszcze w należytym stopniu swojego położenia w przestrzeni europejskiej i możliwości wyjścia z recesji upadającego przemysłu.

Trudności na rynku pracy ilustruje także wskaźnik określający liczbę bezrobotnych przypadających na 1 etat. W kraju wynosi on 45 osób, a na terenie poszczególnych województw wahał się od 115 do 25. Najtrudniejszymi warunkami możliwości zatrudnienia charakteryzują się województwa wschodniego pogranicza: podlaskie (gdzie na 1 etat przypada 113 bezrobotnych), warmińsko-mazurskie (93 bezrobotnych na 1 etat), podkarpackie (75), lubelskie (63) oraz łódzkie (70). Natomiast najkorzystniejszymi warunkami w tym zakresie odznaczają się województwa stosunkowo najlepiej rozwinięte: śląskie (gdzie na jedną ofertę przypada 25 bezrobotnych), dolnośląskie (30), małopolskie (38), wielkopolskie (41) oraz najsilniej powiązane z zachodnimi rynkami pracy województwo opolskie (34).

Tab. 8. Stopa bezrobocia w Polsce (koniec września 2012 r.)

\begin{tabular}{|l|c|c|c|}
\hline \multicolumn{1}{|c|}{ Województwa } & $\begin{array}{c}\text { Stopa } \\
\text { bezrobocia }\end{array}$ & $\begin{array}{c}\text { Liczba } \\
\text { bezrobotnych } \\
\text { na } \mathbf{1} \text { ofertę pracy }\end{array}$ & $\begin{array}{c}\text { Przeciętne miesięczne } \\
\text { wynagrodzenia } \\
\text { brutto w zl }\end{array}$ \\
\hline Wielkopolskie & 9,1 & 41 & 3461,11 \\
\hline Mazowieckie & 10,2 & 53 & 4562,84 \\
\hline Śląskie & 10,4 & 25 & 3856,24 \\
\hline Małopolskie & 10,6 & 38 & 3512,20 \\
\hline Pomorskie & 12,4 & 42 & 3736,28 \\
\hline Dolnośląskie & 12,5 & 30 & 3708,18 \\
\hline Lubelskie & 13,0 & 63 & 3358,71 \\
\hline Łódzkie & 13,2 & 70 & 3430,50 \\
\hline Opolskie & 13,2 & 34 & 3362,20 \\
\hline Podlaskie & 13,8 & 113 & 3100,62 \\
\hline Świętokrzyskie & 14,8 & 52 & 3170,50 \\
\hline Podkarpackie & 15,1 & 75 & 3179,85 \\
\hline Lubuskie & 15,1 & 29 & 3252,90 \\
\hline Kujawsko-pomorskie & 16,7 & 49 & 3422,93 \\
\hline Zachodniopomorskie & 16,7 & 59 & 3136,24 \\
\hline Warmińsko-mazurskie & 19,5 & 93 & \\
\hline
\end{tabular}

Źródło: GUS (2013b). 
Tab. 9. Dynamika dochodów ludności

\begin{tabular}{|c|c|c|c|}
\hline \multirow{2}{*}{ Rok } & Kwartal & $\begin{array}{c}\text { Dynamika dochodów } \\
\text { brutto }\end{array}$ & $\begin{array}{c}\text { Dynamika konsumpcji } \\
\text { prywatnej }\end{array}$ \\
\hline \multirow{3}{*}{2011} & I & $-1,4$ & 3,7 \\
\cline { 2 - 4 } & II & $-0,2$ & 3,6 \\
\cline { 2 - 4 } & III & 1,9 & 3,0 \\
\cline { 2 - 4 } & IV & 2,4 & 2,1 \\
\hline \multirow{2}{*}{2012} & I & $-1,9$ & 2,1 \\
\cline { 2 - 4 } & II & & 1,9 \\
\hline
\end{tabular}

Źródło: Kamińska (2012).

Ograniczanie rynku pracy oraz sytuacja kryzysowa wpłynęły na zmiany tempa dochodów brutto (tab. 9). W pierwszym kwartale 2011 r. dochody spadły o 1,4, a w drugim - o 0,2. Nieznaczny ich wzrost zaznaczył się w czwartym kwartale 2011 r., o 2,4, po czym w pierwszym kwartale 2012 r. spadły o 1,9.

Wpłynęło to na systematyczny spadek dynamiki konsumpcji prywatnej z 3,7 w pierwszym kwartale 2011 r. do 1,9 w drugim kwartale 2012 r. Spadek ten w znacznym stopniu ograniczył popyt na oferowane produkty i wpłynął na dalsze ograniczenia rozmiarów rynku. Było to w pewnym zakresie wynikiem zmniejszania i różnicowania przestrzennego zasilania finansowego gospodarstw domowych. Na koniec września 2012 r. przeciętne dochody miesięcznych wynagrodzeń brutto wahały się od 3,1 tys. w województwie świętokrzyskim i warmińsko-mazurskim oraz 3,2 tys. w województwie podkarpackim i lubuskim do 3,9 w województwie śląskim i 4,5 w województwie mazowieckim (tab. 8).

Wartości tych cech w różnym stopniu różnicują krajową przestrzeń ekonomiczną, co ilustrują wskaźniki zmienności. W najmniejszym stopniu przestrzeń krajową różnicuje przeciętne miesięczne wynagrodzenie, dla którego wartość współczynnika zmienności była najniższa i wynosiła - 10,5, bardziej różnicuje wskaźnik zmienności stopy bezrobocia - 20,4, a najsilniej wskaźnik zmienności liczby bezrobotnych na jedną ofertę pracy - 44,9\%. Podkreśla to szczególnie duży niedobór miejsc zatrudnienia w stosunku do zasobów pracy.

Bardzo zróżnicowane relacje zachodzące między wartościami analizowanych cech występują w poszczególnych województwach, co podkreślają wartości wskaźników korelacji. Najsilniejsze związki zachodzą między stopą bezrobocia a przeciętnym wynagrodzeniem, dla których wartość wskaźnika korelacji była ujemna i wynosiła $(-0,639)$, co oznacza, że w miarę zwiększania się stopy bezrobocia malało przeciętne miesięczne wynagrodzenie brutto. Również ujemna, ale słabsza, korelacja zachodziła między przeciętnym wynagrodzeniem z liczbą bezrobotnych przypadającą na jedną ofertę $(-0,298)$. Natomiast dodatnią korelacją cechowała się stopa bezrobocia i liczba bezrobotnych przypadająca na jedną ofertę, dla której wskaźnik korelacji wyniósł 0,471. Oznacza to, że im wyższe bezrobocie, tym więcej bezrobotnych przypadło na jedno miejsce pracy.

Duże różnicowanie wartości wskaźników oraz relacji zachodzących między nimi wskazuje na dużą żywiołowość tych procesów i przez działania polityki społeczno-gospodarczej winny być one stopniowo ograniczane. W tej sytuacji należy przyjąć, że dalsze ograniczanie strumieni finansowych płynących do gospodarstw domowych oraz postępująca inflacja w zasadniczym stopniu będą nadal ograniczać popyt, nasilać negatywne zjawiska ubóstwa i patologii społecznej. 


\section{Sytuacja wybranych sektorów gospodarczych}

Nasilająca się sytuacja kryzysowa nie stwarzała korzystnych warunków dla pobudzania rozwoju przedsiębiorczości i w różnym stopniu wpływała na zmiany zachowań poszczególnych działów przemysłu (tab. 10). W latach 2011-2012, od stycznia do lipca, odznaczały się one różną zmiennością w zakresie płacy realnej, zatrudnienia, wartości sprzedaży i wydajności pracy. W analizowanym okresie dynamika płacy realnej w poszczególnych działach wahała się od $-3,8$ do 3,4. Najpoważniejszy spadek płacy nastąpił w produkcji komputerów i urządzeń elektrycznych $(-3,8)$, budownictwie $(-2,8)$ i farmacji $(-2,6)$, a w nich średnia płaca w lipcu wahała się od 3,4 tys. zł do 5,3 tys. zł. Natomiast najwyższy wzrost płacy realnej zaznaczył się w produkcji maszyn i urządzeń $(3,4 \%)$, produkcji mebli $(1,5 \%)$, produkcji chemikaliów i wyrobów chemicznych $(1,4 \%)$, przy przeciętnej płacy wahającej się w tych działach od 3,7 tys. zł do 4,5 tys. zł.

W poszczególnych działach poważnym spadkiem odznaczało się zatrudnienie, dzięki któremu najłatwiej można wpływać ma obniżenie kosztów działalności. Stąd dynamika zatrudnienia najbardziej obniżyła się w produkcji odzieży $(-8,3)$, produkcji napojów $(-6,4)$, mebli $(-4,6)$, farmacji $(-3,7)$ i produkcji komputerów $(-3,5)$. Sytuacja ta ma związek w znacznym stopniu ze zmniejszeniem zasobów finansowych gospodarstw domowych, w wyniku czego dużo osób rezygnowało m.in. z zakupu leków (zwłaszcza ludzie starsi). Podobnie trudności na rynku pracy, głównie wśród ludzi młodych, miały związek z ograniczeniem możliwości zakupu mieszkań, co w zasadniczym stopniu wpłynęlo także na spadek produkcji mebli, a w wyniku kryzysu europejskiego - również na ich eksport. Równocześnie wśród biedniejszej części społeczeństwa wzrosło zainteresowanie zakupem tańszej odzieży importowanej z krajów azjatyckich, co wpłynęło na ograniczenie zatrudnienia.

Dużym zróżnicowaniem odznaczała się wartość sprzedaży, co wynika ze zmieniającej się chłonności rynku na oferowane produkty. Szczególnie dużym wzrostem charakteryzowała się

Tab. 10. Zmiana wybranych cech ekonomicznych wg sektorów gospodarczych

\begin{tabular}{|l|c|c|c|c|}
\hline \multirow{2}{*}{ Sektory } & \multicolumn{3}{c|}{ Zmiana od I-VII 2011 do I-VII 2012 } \\
\cline { 2 - 5 } & realnej płacy & zatrudnienia & $\begin{array}{c}\text { wartości } \\
\text { sprzedaży }\end{array}$ & $\begin{array}{c}\text { wydajności } \\
\text { pracy }\end{array}$ \\
\hline Ogółem w firmach od 10 osób & 0,0 & 0,4 & $\mathrm{x}$ & $\mathrm{x}$ \\
\hline Górnictwo & $-0,2$ & 2,2 & $-6,9$ & $-8,9$ \\
\hline Produkcja artykułów spożywczych & $-0,3$ & $-0,3$ & 7,6 & 11,2 \\
\hline Produkcja napojów & $-0,5$ & $-6,4$ & 5,1 & 12,3 \\
\hline Produkcja odzieży & 1,1 & $-8,3$ & 1,0 & 10,1 \\
\hline $\begin{array}{l}\text { Produkcja chemikaliów i wyrobów } \\
\text { chemicznych }\end{array}$ & 1,4 & $-0,3$ & 10,8 & 10,5 \\
\hline Farmacja & $-2,6$ & $-3,7$ & $-8,3$ & $-5,2$ \\
\hline $\begin{array}{l}\text { Produkcja komputerów i wyrobów } \\
\text { elektronicznych }\end{array}$ & $-3,8$ & $-3,5$ & 1,4 & 5,1 \\
\hline Produkcja maszyn i urządzeń & 3,4 & $-1,9$ & 10,5 & 8,4 \\
\hline Motoryzacja & 0,0 & 1,4 & $-3,9$ & $-5,8$ \\
\hline Meble & 1,5 & $-4,6$ & $-5,5$ & $-1,0$ \\
\hline Budownictwo & $-2,8$ & 3,6 & 4,8 & 1,2 \\
\hline Handel detaliczny & 0,6 & 1,4 & $\mathrm{x}$ & $\mathrm{x}$ \\
\hline
\end{tabular}

Źródło: Fandrejewska (2012). 
sprzedaż odzieży, która zwiększyła się o 10,5. Wpłynęła na to produkcja wyrobów o wyższym standardzie, która kierowana jest do ludzi młodych, do bogatszej części społeczeństwa oraz na eksport $^{5}$. Wzrosła także o 10,5 sprzedaż maszyn i urządzeń, wśród z których znaczący udział miały produkty wpływające na zwiększenie wydajności pracy oraz kierowane na eksport. Finansowe ograniczenia zakupów artykułów trwałego użytku wpłynęły na wzrost zakupu drożejących artykułów spożywczych $(7,6)$. Najpoważniejszym spadkiem sprzedaży odznaczają się: wspomniane już wyroby farmaceutyczne $(-8,3)$, meble $(-4,6)$ oraz produkty górnictwa $(-6,9)$, w tym kruszywa na budowę dróg i autostrad.

W wielu działach znacząco wzrosła wydajność pracy, szczególnie w produkcji napojów (o 12,3), artykułów spożywczych (o 11,2) oraz produkcji chemikaliów i odzieży. Było to możliwe dzięki wprowadzaniu do firm nowych i bardziej wydajnych urządzeń, które przyczyniły się z kolei do redukcji zatrudnienia. Natomiast spadek wydajności pracy w farmacji i motoryzacji wynika z czasowego ograniczenia produkcji oraz chęci utrzymania pracowników i przygotowywania się do wzrostu produkcji w okresie wychodzenia z kryzysu. Działy te wymagają stosunkowo wysoko wykwalifikowanej kadry, o którą może być trudno w latach ożywienia gospodarczego.

W warunkach kryzysu zmieniająca się i niepewna sytuacja gospodarcza w kraju i w UE wpływała na różne zachowania przedsiębiorców (pracodawców). Spadek popytu na oferowane produkty wpływa z reguły na ograniczanie liczby pracowników, czego dokonuje się najczęściej w drodze redukcji zatrudnienia. Wobec znacznego obciążenia ekonomicznego przedsiębiorstw w wypadku zwolnień pracodawcy bardziej pesymistycznie oceniali możliwości wzrostu popytu na oferowane produkty, aniżeli okazało się to w rzeczywistości. W konsekwencji w 2012 r. zgłaszali oni znacznie większe zwolnienia grupowe niż zwolnienia, które rzeczywiście się odbyły (tab. 11). Od stycznia do lipca planowali wzrost zwolnień grupowych z 4,5 tys. pracu-

Tab. 11. Planowane i realizowane zwolnienia grupowe w $2012 \mathrm{r}$.

\begin{tabular}{|c|c|c|}
\hline Miesiące & $\begin{array}{c}\text { Zglaszane } \\
\text { zwolnienia przez } \\
\text { pracodawców }\end{array}$ & $\begin{array}{c}\text { Realizacja } \\
\text { zwolnień przez } \\
\text { pracodawców }\end{array}$ \\
\hline I & 4532 & 2111 \\
\hline II & 6692 & 2121 \\
\hline III & 4003 & 1892 \\
\hline IV & 6002 & 2190 \\
\hline V & 6958 & 2796 \\
\hline VI & 7586 & 3371 \\
\hline VII & 9206 & 2617 \\
\hline VIII & 6987 & 3012 \\
\hline IX & 5696 & 6315 \\
\hline X & 6834 & 4119 \\
\hline XI & 4958 & 3711 \\
\hline Razem & 69454 & 34255 \\
\hline
\end{tabular}

Źródło: Fandrejewska (2013: B5).

\footnotetext{
5 Jak pisze W. Raczkowski (2013), ubrania z małych firm odzieżowych zakładanych przez młodych Polaków noszą ludzie na całym świecie. Szczególnie interesująca historia dotyczy marki już światowej „Local Heroes” założonej w lutym 2012 r., którą stworzyły dwie 20-letnie dziewczyny. Wytwarzane przez nie wyroby kierowane do rówieśników są droższe, ale wyróżniają się bardzo dobrą jakością oraz oryginalnymi wzorami i sprzedawane są głównie za pośrednictwem Internetu.
} 
jących do 9,2 tys., a następnie ich spadek do 3,7 tys. w listopadzie, podczas gdy w rzeczywistości początkowo zwolnienia objęły od 2,1 tys. pracowników do 2,6 tys., a następnie osiągnęły 3,7 tys. Podkreśla to dużą niepewność występującą na rynku, która wymusza na przedsiębiorcach dużą ostrożność w zatrudnianiu nowych pracowników. Wynika to być może ze wcześniejszych doświadczeń dotyczących dużych obciążeń związanych ze zwalnianiem pracowników, dlatego tą drogą wolą zmniejszać granice ryzyka.

Kryzys nie wpłynął negatywnie na rozwój sektora usług biznesowych. Najlepsze dla lokalizacji tego typu działalności są metropolie dysponujące dużymi zasobami wysoko wykwalifikowanych kadr, dużym doświadczeniem i innowacyjnością oraz niższymi kosztami pracy w stosunku do światowych metropolii. Dzięki tym czynnikom oraz rozwiniętej infrastrukturze telekomunikacyjnej krajowe metropolie stają się coraz bardziej atrakcyjne dla rozwijania tego typu działalności na rzecz światowych korporacji. W latach 2003-2012 liczba centrów systematycznie rosła (z 69 do 350, czyli był to ponadpięciokrotny wzrost) i stworzono miejsca pracy dla ok. 100 tys. pracowników. Na koniec 2011 r. w centrach zlokalizowanych w Krakowie pracowało 19,4 tys. osób, w Warszawie - 14,2 tys., we Wrocławiu - 12,6 tys., w Trójmieście - 8,0 tys., Łodzi - 7,7 tys., aglomeracji śląskiej - 6,9 tys., w Poznaniu - 5,0 tys.

W ramach redukcji kosztów wiele korporacji planuje przenoszenia swojej działalności z Singapuru do Polski. Przewiduje się dalszy rozwój usług o charakterze analitycznym, co wymaga wdrażania nowych rozwiązań technologicznych oraz kształcenia przyszłych pracowników. Dzięki temu Polska jest drugim krajem po Indiach o największej liczbie specjalistów do realizacji nowoczesnych usług biznesowych, mającym pracowników o coraz wyższym poziomie wykształcenia i znajomości języków obcych. Należy zaznaczyć, że ten sektor w znacznym stopniu nawiązuje do współczesnych tendencji rozwoju cywilizacyjnego, przyczyniając się do kształtowania społeczeństwa informacyjnego i budowania gospodarki opartej na wiedzy. Stąd w małym stopniu wpływać będzie na niego sytuacja kryzysowa, tym bardziej, że umożliwia on zwiększanie wydajności pracy.

\section{Sytuacja finansowa}

Sytuacja kryzysowa ograniczająca możliwości rozwoju przedsiębiorczości prowadzi z jednej strony do pojawiania się zadłużenia, a z drugiej strony - do zwiększenia oszczędzania w gospodarstwach domowych i przedsiębiorstwach.

W warunkach kurczenia się rynków pracy oraz relatywnego spadku siły nabywczej gospodarstw domowych znacznie rośnie zadłużenie Polaków w kredytach konsumpcyjnych (tab. 12). Szczególnie silny wzrost zaznaczył się w latach rozwoju ekonomicznego (2005-2009), kiedy wartość tych kredytów zwiększyła się z 49,1 mld zł do 127,6 mld zł, czyli ponaddwuipółkrotnie. W miarę stabilne warunki zatrudnienia i możliwości wzrostu płacy, a także oferowane różnorodne produkty instytucji finansowych zachęcały do zaciągania kredytów, zwłaszcza na zakup mieszkań, budowę domów i ich wyposażenie. Zmniejszenie zainteresowania kredytami nastąpiło w latach kryzysu. W latach 2010-2012 zadłużenie spadło z 141,3 mld zł do 127,1 mld zł. Redukcja zatrudnienia i ograniczanie wzrostu wynagrodzeń bardzo często uniemożliwiały spłaty zaciągniętych kredytów oraz stawiały gospodarstwa domowe w kłopotliwej sytuacji. Pojawiły się także większe problemy z zaciąganiem kredytów związane z ograniczaniem tego typu działalności szczególnie przez banki z kapitałem zagranicznym, które w sytuacji kryzysowej kierują swoje aktywa do krajów, w których są siedziby ich zarządów.

Ważnym czynnikiem możliwości ożywienia gospodarczego są zasoby finansowe przedsiębiorstw, które mogą być przeznaczone na nowe inwestycje i tworzenie nowych miejsc pracy, zasoby finansowe gospodarstw domowych, których uruchomienie pozwala na pobudzenie 
Tab. 12. Zadłużenie Polaków w kredytach konsumpcyjnych w latach 2005-2012

\begin{tabular}{|c|c|c|c|}
\hline \multirow{2}{*}{ Rok } & \multirow{2}{*}{$\begin{array}{c}\text { Wartość } \\
\text { w mld zl }\end{array}$} & \multicolumn{2}{|c|}{ Dynamika } \\
\cline { 3 - 4 } & & rok poprzedni $=\mathbf{1 0 0}$ & $\mathbf{2 0 0 5}=\mathbf{1 0 0}$ \\
\hline I 2005 & 49,1 & 100,0 & 100,0 \\
\hline I 2006 & 59,2 & 120,6 & 120,6 \\
\hline I 2007 & 72,4 & 122,3 & 147,5 \\
\hline I 2008 & 96,3 & 133,0 & 196,1 \\
\hline I 2009 & 127,6 & 132,5 & 259,9 \\
\hline I 2010 & 140,9 & 110,4 & 287,0 \\
\hline I 2011 & 141,3 & 100,3 & 287,8 \\
\hline I 2012 & 137,1 & 97,0 & 279,2 \\
\hline IX 2012 & 133,9 & 97,7 & 272,7 \\
\hline
\end{tabular}

Źródło: Semciuk (2012, 10-11 listopada: 8; 2012, 13 listopada: 23).

rynku, oraz stabilność gospodarcza i polityczna kraju, gwarantująca stałość uwarunkowań działalności gospodarczej i rozwoju przedsiębiorczości.

Część firm krajowych odznacza się poważnymi zasobami finansowymi, ale część charakteryzuje się poważnym zadłużeniem (tab. 13). Oszczędności firm wynikają z chęci uniknięcia ryzyka związanego z kredytowaniem przez instytucje finansowe oraz braku stabilności gospodarczej. Wpływa to w zasadniczym stopniu na chęć utrzymania zgromadzonych środków, które mogą okazać się bardzo przydatne w latach ożywienia gospodarczego i wychodzenia z kryzysu. W wyniku chwiejnej sytuacji gospodarki światowej i braku jasnych reguł funkcjonowania gospodarki krajowej oszczędności, którymi dysponują firmy, wykazywały systematyczny wzrost. W latach 2005-2011 zwiększyły się one z $101 \mathrm{mld}$ zł do 183 mld zł, tj. do 181,2\%. Równocześnie w tym czasie w wielu firmach w coraz szybszym tempie rosło zadłużenie z 119 mld zł do 232 mld zł, tj. do 195,0\%.

Z badań prowadzonych z trzecim kwartale 2011 r. wynika, że spośród barier rozwoju działalności przedsiębiorcy na czoło wysuwają: niski popyt rynku (14\%), wzrost cen surowców (11,2\%), wysokość opłat, w tym wahania kursów walutowych $(9,9 \%)$, zatory płatnicze $(6,8 \%)$ oraz nasilającą się konkurencję (6,8\%). Natomiast wśród barier prowadzenia firm za najważniejsze uważają: skomplikowane procedury prawne $(35 \%)$, niejasne prawo $(33 \%)$, zły system podatkowy (29\%), wysokie koszty pracy (14\%) oraz wysokie koszty finansowania, nasilającą się konkuren-

Tab. 13. Sytuacja finansowa firm krajowych w latacj 2005-2011

\begin{tabular}{|c|c|c|c|c|}
\hline Rok & $\begin{array}{c}\text { Oszczędności } \\
\text { firm w mld zl }\end{array}$ & $\begin{array}{c}\text { Zadłużenie firm } \\
\mathbf{w} \text { mld zl }\end{array}$ & $\begin{array}{c}\text { Dynamika } \\
\text { oszczędności }\end{array}$ & $\begin{array}{c}\text { Dynamika } \\
\text { zadłużenia }\end{array}$ \\
\hline 2005 & 101 & 119 & 100,0 & 100,0 \\
\hline 2006 & 127 & 136 & 125,7 & 114,3 \\
\hline 2007 & 144 & 168 & 142,6 & 141,2 \\
\hline 2008 & 151 & 216 & 149,5 & 181,5 \\
\hline 2009 & 166 & 207 & 164,4 & 173,9 \\
\hline 2010 & 183 & 204 & 181,2 & 171,4 \\
\hline 2011 & 183 & 232 & 181,2 & 195,0 \\
\hline
\end{tabular}

Źródło: Koniunktura coraz słabsza (2011). 
cję, niski popyt na produkty i usługi, brak środków na rozwój, biurokracja, niedobór pracowników o odpowiednich kwalifikacjach zawodowych, nierzetelność kontrahentów i brak wsparcia ze strony rządu.

W konsekwencji głównym źródłem finansowania działalności różnej wielkości firm są środki własne, a w mniejszym stopniu kredyty. Szczególnie wysokim udziałem środków własnych charakteryzują się mikrofirmy, które opierają się na nich w 56,8\%, a także małe firmy $(42,9 \%)$ i średnie firmy $(43,6 \%)$. Natomiast z kredytów bankowych korzysta odpowiednio $22,8 \%, 27,3 \%$ i $24,9 \%$ firm $^{6}$. Stworzenie warunków wpływających na wykorzystanie własnych zasobów finansowych może być ważnym czynnikiem zdynamizowania rozwoju gospodarczego, które jest możliwe głównie dzięki stabilności rozwoju przedsiębiorczości w warunkach ograniczanie wspomnianych barier rozwoju działalności i barier w zakresie prowadzenia firm.

Rynek krajowy w znacznym stopniu może także pobudzić aktywizacja zasobów finansowych ludności. W zależności od potrzeb mogą być one przeznaczone na konsumpcję, inwestycje lub pozostawione jako oszczędności. W obecnej sytuacji ekonomicznej gospodarstwa domowe dysponują znacznymi środkami finansowymi, na co wskazują rosnące wartości depozytów zgromadzonych w instytucjach finansowych (tab. 14). W latach 2011-2012 z miesiąca na miesiąc wartość depozytów systematycznie rosła z 423,9 mld zł do 505, 2 mld zł, tj. do 119,2\% ${ }^{7}$. Szczególnie wysoka dynamika zaznaczała się od maja do grudnia 2011 r., nastąpił wzrost z 100,7 do 102,9, po czym była niższa: od 99,8 do 100,1. W obawie przed nasilającym się kryzysem ekonomicznym gospodarstwa domowe, podobnie jak firmy, oszczędzały swoje zasoby finansowe na wypadek pogarszającej się kondycji ekonomicznej rodzin. Najpewniejszym środkiem zabezpieczenia były relatywnie korzystne stopy procentowe oferowane zwłaszcza przez banki związane z kapitałem zagranicznym. Wyższe stopy procentowe tych banków wynikały z potrzeb finansowych krajów, na terenie których zlokalizowane były ich siedziby zarządów. Stąd atrakcyjniejsze dla lokowania oszczędności były oddziały banków zagranicznych aniżeli banki z kapitałem krajowym, oferujące znacznie niższe odsetki ${ }^{8}$. Oszczędności społeczeństwa nie wspierały więc rozwoju gospodarki krajowej, ale gospodarki innych krajów. Wydaje się, że jest to wyrazem braku umiejętności racjonalnego zarządzania zgromadzonymi oszczędnościami społeczeństwa przez krajowe elity gospodarcze i polityczne.

\footnotetext{
${ }^{6}$ Według badań z października 2012 r. na najbliższe miesiące planuje utrzymać obecny poziom zatrudnienia $54 \%$ firm, nieznaczną i znaczną redukcję zatrudnienia planuje $30 \%$ firm, a tylko $3 \%$ planuje znaczny wzrost zatrudnienia. Natomiast rezygnację z planów inwestycyjnych przewiduje $34 \%$ firm, a nieznaczne inwestycje - 37\% (Błaszczak, 2012).

${ }^{7} \mathrm{O}$ rozmiarach oszczędności gospodarstw domowych świadczy porównanie ich do wartości PKB. W $2010 \mathrm{r}$. PKB w Polsce wynosiło 469,3 mld dol., co przy aktualnym kursie ( 1 dolar $=$ ok. 3 zł) wynosi 1407,9 mld zł. Przy takim założeniu wartość depozytów - 505,2 mld zł - stanowi 35,9\%.

8 Jednym z ważnych instrumentów mających na celu ograniczanie oszczędności i wzrost popytu wewnętrznego (zakupów) jest regulowanie stopy procentowej przez Radę Polityki Pieniężnej. Od listopada ubiegłego roku czterokrotnie obniżała ona stopy procentowe o 0,25 punktów procentowych. Wpływa to na ograniczania oszczędności i wzrost obrotów rynkowych. Na kryzys w kraju w zasadniczym stopniu wpływa otoczenie zewnętrzne, zwłaszcza kryzys w strefie euro. Firmy ograniczają inwestycje i produkcję, co przekłada się na pogarszanie się sytuacji na rynku pracy. Trudności na rynku pracy i wzrost bezrobocia oraz zmniejszanie się podwyżek płac i zarobków powodują zmniejszenie popytu konsumpcyjnego. W konsekwencji w grudniu 2012 r. nastąpił spadek wartości towarów o 10,6\%, a zakupy zmniejszyły się o 2,5\% i częściowo czynione były z wcześniej zgromadzonych oszczędności. Trudno o zwiększenie popytu, jeżeli tempo wzrostu płac i inflacja były na tym samym poziomie $-2,4 \%$ (Baj, 2013).
} 
Tab. 14. Depozyty gospodarstw domowych w Polsce w latach 2011-2012

\begin{tabular}{|c|c|c|c|c|}
\hline Lata & Miesiące & $\begin{array}{l}\text { Wartość depozy- } \\
\text { tów w mld zl }\end{array}$ & $\begin{array}{l}\text { Miesiąc } \\
\text { poprzedni } \\
=100\end{array}$ & $\begin{array}{c}\text { Dynamika } \\
\text { (I } 2011=\mathbf{1 0 0})\end{array}$ \\
\hline \multirow{12}{*}{2011} & $\mathrm{I}$ & 423,9 & 100,0 & 100,0 \\
\hline & II & 430,4 & 101,5 & 101,5 \\
\hline & III & 433,7 & 100,8 & 102,3 \\
\hline & IV & 434,5 & 100,2 & 102,5 \\
\hline & $\mathrm{V}$ & 432,7 & 99,6 & 102,1 \\
\hline & VI & 435,9 & 100,7 & 102,8 \\
\hline & VII & 440,1 & 101,0 & 103,8 \\
\hline & VIII & 445,4 & 101,2 & 105,1 \\
\hline & IX & 452,4 & 101,6 & 106,7 \\
\hline & $\mathrm{X}$ & 456,4 & 100,9 & 107,7 \\
\hline & XI & 464,4 & 101,8 & 109,6 \\
\hline & XII & 478,0 & 102,9 & 112,8 \\
\hline \multirow{11}{*}{2012} & I & 486,2 & 101,7 & 114,7 \\
\hline & II & 488,1 & 100,4 & 115,1 \\
\hline & III & 487,3 & 99,8 & 115,0 \\
\hline & IV & 486,2 & 99,8 & 114,7 \\
\hline & $\mathrm{V}$ & 488,9 & 100,6 & 115,3 \\
\hline & VI & 493,1 & 100,9 & 116,3 \\
\hline & VII & 494,7 & 100,3 & 116,7 \\
\hline & VIII & 498,3 & 100,7 & 117,6 \\
\hline & IX & 499,2 & 100,2 & 117,8 \\
\hline & $\mathrm{X}$ & 504,5 & 101,1 & 119,0 \\
\hline & XI & 505,2 & 100,1 & 119,2 \\
\hline
\end{tabular}

Ryc. 9. Wzrost liczby depozytów w gospodarstwach domowych (w mld zł)

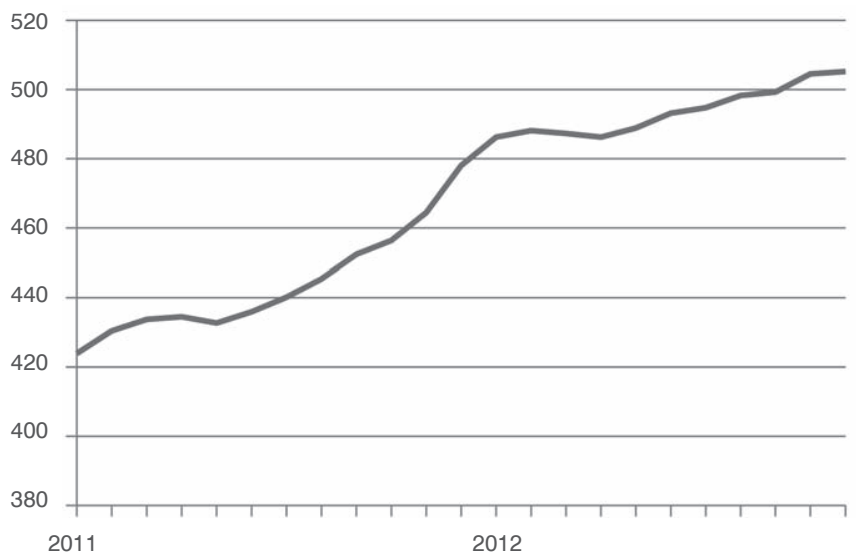

Źródło: Krześniak (2013: 10B). 


\section{Uwarunkowania instytucjonalne}

Znaczącą barierą dla rozwoju przedsiębiorczości jest jakość uwarunkowań stwarzanych przez instytucje państwowe. Wskazuje na to ocena możliwości rozwoju przedsiębiorczości przez Bank Światowy. Na 183 badane kraje Polska pod względem analizowanych cech zajmowała stosunkowo odległe miejsca. Pod względem: wolności gospodarczej nasz kraj zajmował 62 pozycję, pod względem możliwości odzyskania należności od podmiotów gospodarczych i instytucji znajdował się na 87 pozycji, pod względem rejestrowania nieruchomości na 89, pod względem systemu opłacania podatków na 128, a pod względem uzyskania zezwolenia na budowę zajmował 160 pozycję 9 .

Równocześnie Polska jest atrakcyjna dla przejęć przez kapitał światowy. Na maksymalną liczbę punktów - 100 - ma 92 punkty i zajmuje pierwsze miejsce w Europie pod względem jakości kapitału ludzkiego (wg opinii Polacy są bardzo dobrze wykształceni i posiadają wysokie kwalifikacje zawodowe). Wysoko, na 92 punkty, ocenione zostały również warunki demograficzne naszego kraju, a na 89 punktów - wzrost PKB.

Pod względem regulacji prawno-politycznych (liczba formalności, które trzeba spełnić przy zakładaniu działalności gospodarczej) oceniono Polskę tylko na 29 punktów, a pod względem liczby dni oczekiwania na decyzję w sprawie nabycia aktywów przez jedną firmę od innej już tylko na 7 punktów $^{10}$.

Znaczną przeszkodą w rozwoju przedsiębiorczości jest jakość aparatu fiskalnego i prawniczego, który doprowadza do upadków wiele dobrze rozwijających się firm, przykładami są firmy Optimus w Nowym Sączą, stocznie ${ }^{11}$, Bestcom w Poznaniu, Atrax w Gdańsku, wrocławski dystrybutora sprzętu komputerowego JTT Computer, PHUP w Chmielniku, sieć kantorów Comti i in.

Przedstawione bariery rozwoju przedsiębiorczości wynikają także ze słabości władzy, która nie jest w stanie ich usunąć na gruncie właściwie uchwalonego i egzekwowania prawa. W znacznym stopniu spowodowane jest to także niechęcią lub niskimi kwalifikacjami niektórych przedstawicieli władzy oraz brakiem odpowiedzialności niektórych przedstawicieli administracji za popełnione błędy, które przyczyniają się do ograniczania działalności lub upadku dobrze prosperujących podmiotów gospodarczych i niszczenia związanych z nimi przedsiębiorców ${ }^{12}$. Jest to związane silnie z urzędniczą mentalnością przyjętą często przez nowe elity z lat centralnego systemu gospodarowania, kiedy to urzędnicy zobowiązani byli do niszczenia obywateli najbardziej aktywnych na polu rozwijania działalności gospodarczej. Równocześnie z trudem dociera do nich świadomość, że to przedsiębiorcy, a nie politycy w głównej mierze przyczyniają się do rozwoju ekonomicznego kraju. Dlatego należy się zgodzić z opinią A. Górala,

${ }^{9}$ Podobnie w ocenie Heritage Foudation pod względem wolności gospodarczej Polska zajęła 64 miejsce (Wybranowski, 2011, 2012).

${ }^{10}$ Nadto pod względem wielkości i wzrostu PKB oceniono Polskę na 89 punktów, pod względem stabilności politycznej - na 84 punkty, pod względem technologicznych czynników wzrostu (eksport wyrobów techniki zaawansowanej) - 74 punkty, jakości dróg - 64 punkty, podczas gdy Czesi otrzymali maksymalną wartość 100 punktów (Woźniak, 2012).

${ }^{11}$ Por. Gadomski (2011).

${ }^{12}$ Należy się zastanowić, co zostaje z człowieka, który niesłusznie jest zatrzymany, przesłuchiwany i opisywany przez środki masowego przekazu jako nieuczciwy przedsiębiorca, a następnie po 5-7 latach zostaje w wyniku kolejnego procesu uniewinniony, oraz jakie to budzi reperkusje społeczne i w jakim stopniu przyczynia się do odgraniczenia wiarygodności państwa przez społeczeństwo (por. np. Wybranowski, 2012, 2013; Pietryga, 2013). 
prezesa i udziałowca Asseco Poland ${ }^{13}$, który tak wypowiedział się na temat polskiego patriotyzmu: „Dziś o dobrobycie i przyszłości każdego państwa decyduje gospodarka [...]. Powinniśmy współpracować w celu budowania silnych polskich firm i naszej gospodarki. [...] jako kraj na dorobku potrzebujemy przemyślanej dyskusji o ekonomii i gospodarce. [...] z podziwem przyglądam się rządom, które aktywnie wspierają rozwój rodzimych firm. [...] podczas ostatnich 20 lat nie zbudowaliśmy prawdziwie globalnych polskich firm. To gospodarka jest prawdziwym spoiwem społeczeństwa w krajach wysoko rozwiniętych"14.

Również braki budżetowe gmin i sposoby zarządzania na szczeblu lokalnym nie stwarzają korzystnych warunków dla rozwijania się małych firm. Gminy wyznaczają zazwyczaj maksymalne stawki podatkowe za przejmowane przez małe podmioty gospodarcze nieruchomości, które wcześniej zostały opuszczane, a nawet niekiedy zostały już poważnie zdewastowane i wymagają doprowadzenia mediów (wody, kanalizacji, prądu). Ze strony przedsiębiorców wymaga to poniesienia poważnych nakładów na remonty ${ }^{15}$. Gminy nie biorą pod uwagę, że przejmowanie i modernizacja zdekapitalizowanych budynków ogranicza ich dalszą dekapitalizację i podnosi jakość fizjograficzną układu lokalnego.

Oznacza to, że bardzo poważne zadanie stoi przed władzami publicznymi, które powinny traktować problemy gospodarcze jako podstawowy cel swojego działania. Wymaga to jednak przebudowy myślenia oraz umiejętności posługiwania się wiedzą ekonomiczną, która pozwoli na kreowanie wspierających instrumentów prawnych oraz ograniczania możliwości zjawisk patologicznych zarówno w biznesie, jak i w strukturach społecznych.

\section{Procesy migracji}

Należy wnosić, iż w niedalekiej przyszłości w gospodarce krajowej pojawi się nowy czynnik ograniczający rozwój przedsiębiorczości, którym będą braki kadrowe. Pod koniec 2013 r. należy się liczyć z tym, że rozpocznie się wychodzenie z kryzysu i nastąpi pobudzenie gospodarcze. Najwcześniej proces ten zaznaczy się na terenie krajów ekonomicznie rozwiniętych (Niemiec, Wielkiej Brytanii, Francji), co pociągać będzie za sobą wzrost ich zapotrzebowania na nowych pracowników. Dopiero później zaznaczy się osłabienie kryzysu w krajach słabiej rozwiniętych, w tym w Polsce. Niewątpliwie nasili to migracje zarobkowe z Polski do krajów zachodnich, które wraz z wychodzeniem z kryzysu stwarzać będą nowe, bardziej konkurencyjne miejsca pracy. Nastąpi więc odpływ z naszego kraju zwłaszcza młodych i lepiej wykształconych pracowników do krajów zachodnich, które już wcześniej stwarzały dla nich atrakcyjne miejsca pracy. Procesy migracji zarobkowej zaznaczały się także w okresie niewielkiego ożywienia gospodarczego. W latach 2011-2012 liczba emigrantów z Polski wzrosła z 1,6 mln osób do 1,7 mln. Najpopularniejsze kierunki migracji obejmowały tradycyjnie Wielką Brytanię (wzrost

${ }^{13}$ Asseco Poland zaliczana jest do światowej czołówki firm informatycznych, działa w kilkudziesięciu krajach na całym świecie, w 2011 r. zajmowała 51 pozycję wśród 2000 największych polskich przedsiębiorstw, mając przychody ze sprzedaży w wysokości blisko 3 mld zł, kapitał własny - 9,5 mld zł, zatrudniając 14,5 tys. pracowników i mając wypracowany wynik netto w wysokości 0,6 mld zł (Polskie przedsiębiorstwa. Lista 2000, 2012). W 2012 r., wg szacunków, wartość przychodów ze sprzedaży wyniosła ponad $5 \mathrm{mld}$ zł.

${ }^{14}$ Następnie na gruncie gospodarki i funkcjonowania firm autor przedstawia własną ideę budowania patriotyzmu gospodarczego jako niezbędnego czynnika rozwoju pastwa i społeczeństwa w nowych uwarunkowaniach gospodarki rynkowej (Góral, 2013).

15 Organy władzy lokalnej nie biorą pod uwagę, że przejmowane budynki nie spełniają norm przeciwpożarowych i sanitarnych (Pogroszewska, 2013). 
Tab. 15. Najpopularniejsze kierunki migracji Polaków w latach 2011 i 2012 (w tys.)

\begin{tabular}{|l|c|r|r|r|r|}
\hline \multirow{2}{*}{ Kraj } & \multirow{2}{*}{$\mathbf{2 0 1 1}$} & \multirow{2}{*}{$\mathbf{2 0 1 2}$} & \multirow{2}{*}{ Dynamika } & \multicolumn{2}{c|}{ Udzial } \\
\cline { 5 - 6 } & & & & $\mathbf{2 0 1 1}$ & $\mathbf{2 0 1 2}$ \\
\hline W. Brytania & 580 & 625 & 107,8 & 35,4 & 36,4 \\
\hline Niemcy & 440 & 470 & 106,8 & 26,9 & 27,4 \\
\hline Irlandia & 133 & 120 & 90,2 & 8,1 & 7,0 \\
\hline Holandia & 92 & 95 & 103,3 & 5,6 & 5,5 \\
\hline Włochy & 92 & 94 & 102,2 & 5,6 & 5,5 \\
\hline Francja & 60 & 62 & 103,3 & 3,7 & 3,6 \\
\hline Norwegia & 50 & 56 & 112,0 & 3,1 & 3,3 \\
\hline Belgia & 45 & 47 & 104,4 & 2,7 & 2,7 \\
\hline Hiszpania & 38 & 40 & 105,3 & 2,3 & 2,3 \\
\hline Szwecja & 33 & 36 & 109,1 & 2,0 & 2,1 \\
\hline Austria & 29 & 25 & 86,2 & 1,8 & 1,5 \\
\hline Dania & 19 & 21 & 110,5 & 1,2 & 1,2 \\
\hline Grecja & 16 & 15 & 93,8 & 1,0 & 0,9 \\
\hline Czechy & 7 & 7 & 100,0 & 0,4 & 0,4 \\
\hline Finlandia & 3 & 2 & 66,7 & 0,2 & 0,1 \\
\hline Portugalia & 1 & 1 & 100,0 & 0,1 & 0,1 \\
\hline Razem & 1638 & 1716 & 104,8 & 100,0 & 100,0 \\
\hline
\end{tabular}

Źródło: Maciejewicz, Kadłuczka (2011); Ćwiek (2012).

Tab. 16. Zarobki w Europie w 2010 r.

\begin{tabular}{|l|c|c|l|c|c|}
\hline \multicolumn{1}{|c|}{ Kraj } & $\begin{array}{c}\text { Zarobki } \\
\text { (euro w tys. } \\
\text { rocznie) }\end{array}$ & $\begin{array}{c}\text { Bezrobocie } \\
\text { (w procentach) }\end{array}$ & Kraj & $\begin{array}{c}\text { Zarobki } \\
\text { (euro w tys. } \\
\text { rocznie) }\end{array}$ & $\begin{array}{c}\text { Bezrobocie } \\
\text { (w procentach) }\end{array}$ \\
\hline Norwegia & 28,6 & 3,4 & Hiszpania & 15,9 & 21,0 \\
\hline Luksemburg & 27,1 & 4,5 & Grecja & 11,2 & 15,0 \\
\hline Austria & 25,7 & 4,0 & Portugalia & 10,9 & 12,2 \\
\hline Belgia & 25,5 & 7,4 & Słowenia & 9,3 & 8,4 \\
\hline Dania & 25,2 & 7,2 & Łotwa & 8,3 & 16,2 \\
\hline Niemcy & 24,9 & 6,1 & Czechy & 7,1 & 6,5 \\
\hline Holandia & 24,4 & 4,1 & Estonia & 6,4 & 13,8 \\
\hline Finlandia & 23,3 & 7,8 & Słowacja & 5,7 & 13,4 \\
\hline Szwecja & 22,4 & 7,5 & Węgry & 5,7 & 9,9 \\
\hline Irlandia & 21,9 & 14,2 & Polska & 5,4 & 9,0 \\
\hline W. Brytania & 20,7 & 7,7 & Litwa & 4,5 & 16,3 \\
\hline Francja & 20,3 & 7,7 & Rumunia & 3,2 & 7,0 \\
\hline Włochy & 18,4 & 8,0 & Bułgaria & 2,2 & 11,4 \\
\hline
\end{tabular}

Źródło: Bojanowski, Bednarek (2011: 25). 
emigracji z 580 tys. do 625 tys. osób), Niemcy (wzrost emigracji z 440 tys. do 470 tys.osób), a następnie Irlandię, Holandię, Włochy, Francję i in. (tab.15). Proces ten nasilać będzie deficyt zasobów pracy w tych krajach, na co wskazuje stosunkowo niski poziom bezrobocia, np. w $2010 \mathrm{r}$. w Niemczech stopa bezrobocia wynosiła 6,1\%, w Wielkiej Brytanii 7,7\%, Holandii 4,1\%, Norwegii 3,4\%. Dodatkowym czynnikiem aktywizującym migrację są relatywnie wysokie płace w tych krajach. Podczas gdy w 2010 r. przeciętne roczne zarobki w Polsce wynosiły 5,4 tys. euro, to w Norwegii wynosiły one 28,6 tys. euro, w Niemczech $-24,9$ tys., w Holandii 24,4 tys., a w Wielkiej Brytanii - 20,7 tys. (tab. 16) ${ }^{16}$. Między wysokością zarobków w tych krajach a stopą bezrobocia zachodzi wyraźna prawidłowość, a mianowicie w miarę spadku stopy bezrobocia rosną zarobki, co ilustruje wartość wskaźnika korelacji $(-0,532)$.

Należy wnosić, że na proces ten wpływać będzie także zarysowująca się niekorzystna sytuacja na krajowym rynku pracy. Przewiduje się, że w 2013 r. stopa bezrobocia będzie wynosić 13,0\%, a dopiero następnie zacznie spadać do 11,1\% w 2016 r., co oznacza, że stosunkowo długo utrzymywać się będą trudności w zakresie aktywizacji zawodowej ludności na krajowym rynku pracy ${ }^{17}$.

\section{Zakończenie}

Zarysowany problem uwarunkowania rozwoju przedsiębiorczości w warunkach kryzysu gospodarczego i wybrane przykłady wskazują na bardzo złożony mechanizm kształtowania tego zjawiska. W celu podejmowania racjonalnych działań wpływających na pobudzanie rozwoju przedsiębiorczości mechanizm ten należy w miarę precyzyjnie poznać i upowszechnić zarówno wśród przedstawicieli władzy, jak i w społeczeństwie. Wydaje się, że główną przyczyną współczesnego stanu są niezbyt sprawnie działające reguły demokracji, w których brakuje konkurencji intelektualnej i umiejętności posługiwania się wiedzą przez znaczną część elit politycznych, wybieranych przez słabo ekonomicznie wyedukowane społeczeństwo ${ }^{18}$. Wyrazem tego może być podejmowanie zastępczych problemów przez władze ustawodawcze oraz niewiele dające spory polityczne, w których brak treści gospodarczych. Wynika to niewątpliwie z faktu, iż na temat zastępczo podejmowanych spraw może dyskutować każdy, natomiast dyskusje merytoryczne o tym, jak wyprowadzić kraj z kryzysu i przygotować do wejścia w fazę ożywienia gospodarczego, wymagają już poważnej wiedzy ekonomicznej, społecznej i o zmieniających się uwarunkowaniach międzynarodowych. W miejsce obecnych, czasem sztucznie wywoływanych sporów, elity polityczne powinny podjąć stale aktualny problem, mianowicie jak budować nowoczesne państwo w warunkach wkraczania w informacyjną fazę rozwoju. Dlatego na wszystkich szczeblach edukacji i w środkach masowego przekazu coraz większego znaczenia powinno nabierać przekazywanie wiedzy z zakresu kształtowania postaw przedsiębiorczych w zmieniającym się otoczeniu europejskim i światowym, które można wykorzystać dla intensyfikowania procesów rozwoju społecznego, gospodarczego i kulturowego kraju, a także układów regionalnych i lokalnych. Podstawowym celem tych działań winno być kształtowanie społeczeństwa informacyjnego i gospodarki opartej na wiedzy.

\footnotetext{
$\overline{16}$ Por. Macierewicz, Kadłuczka (2011).

${ }^{17}$ Jeżeli przewidywania te okażą się trafne i nie dokona się znaczniejszego przyspieszenia rozwoju gospodarczego, to należy się liczyć z bardzo negatywnym zjawiskiem ubytku głównie młodych i najlepiej wykształconych pracowników, co znacznie osłabiać będzie możliwości rozwijania gospodarki w latach pokryzysowych (Cieślak-Wróblewska, 2012).

18 Połowa Polaków twierdzi, że ma za mało koniecznej wiedzy, by prowadzić własną działalność gospodarczą (Błaszczak, 2012, 1 sierpnia).
} 


\section{Literatura}

Baj, L. (2013, 7 lutego). Stopy procentowe znowu w dół o ćwiartkę. Kiedy koniec obniżek?. Gazeta Wyborcza.

Błaszczak, A. (2012, 12 listopada). Rosną obawy najmniejszych firm. Rzeczpospolita.

Błaszczak, A. (2012). Kurs na przedsiębiorczość. Rzeczpospolita.

Bojanowski, M., Bednarek, M. (2011, 8 sierpnia). Praca u podstaw. Gazeta Wyborcza, 25.

Cieślak-Wróblewska, A. (2012, 14 września). Nieprędki powrót szybkiego wzrostu. Rzeczpospolita.

Ćwiek, J. (2012, 26 września). Polacy znów masowo rmigrują do Londynu. Rzeczpospolita.

Fandrejewska, A. (2012, 27 sierpnia). Nie widać końca redukcji płac. Rzeczpospolita, B2-3.

Fandrejewska, A. (2013, 11 stycznia). Mniej zwolnień niż zapowiedzi. Rzeczpospolita, B5.

Gadomski, W. (2011, 11 lutego). Państwo zniszczyło stocznie. Gazeta Wyborcza.

GUS. (2010). Rocznik Statystyczny RP, Warszawa.

GUS. (2013a). Zatrudnienie i wynagrodzenia w gospodarcze narodowej w 2012 r., Warszawa.

GUS. (2013b). Zatrudnienie i wynagrodzenia w gospodarce narodowej w I-III kwartale 2012 r., Warszawa.

Góral, A. (2013, 4 lutego). Patriota płaci podatki w Polsce. Rzeczpospolita.

Kamińska, A. (2012, 24 sierpnia). Pensje nie wystarczają, Polacy sięgają po oszczędności. Rzeczpospolita B.

Koniunktura coraz słabsza. (2011, 22-23 października). Rzeczpospolita B.

Krześniak, M. (2013, 9 stycznia). Odsetki od lokat będą topniały. Rzeczpospolita, 10B.

Macierewicz, P., Kadłuczka, J. (2011, 8 sierpnia; 2012, 26 czerwca). Wyjeżdżają i nie wracają. Gazeta Wyborcza.

Misztal, S., Zioło, Z. (red.). (1998). Dorobek polskiej geografii przemystu. Komisja Geografii Przemysłu Polskiego Towarzystwa Geograficznego, Instytut Geografii WSP im. Komisji Edukacji Narodowej w Krakowie, Wydawnictwo Krakowskiego Oddziału PAN, Warszawa - Kraków.

Pietryga, T. (2013, 6 lutego). Przedsiębiorcy i myśliwi. Rzeczpospolita.

Pogroszewska, M. (2013, 7 lutego). Podatek od rudery bez taryfy ulgowej. Rzeczpospolita.

Polskie przedsiębiorstwa. Lista 2000 (2012, 24 października), Rzeczpospolita.

Rachwał, T. (2001). Problematyka kwestionariusza badań funkcjonowania przedsiębiorstwa przemysłowego w okresie transformacji systemu gospodarowania. Prace Komisji Geografii Przemyslu Polskiego Towarzystwa Geograficznego, 2, 49-57.

Raczkowski, W. (2013). Szyją i promują Polskę, Przegląd, 5.

Reda-Jakima, Z. (2013, 9 stycznia). Liczba upadłości rośnie szybciej niż w Hiszpanii. Rzeczpospolita, B3.

Semciuk, M. (2012, 10-11 listopada). Niepewny koniec kredytowej smuty w polskich bankach. Gazeta Wyborcza, 8.

Semciuk, M. (2012, 13 listopada). Urzędy stworzą bat na lichwę?. Gazeta Wyborcza, 23.

Więcław, E. (2010, 6 stycznia). Źle zarządzane firmy będą znikać. Rzeczpospolita.

Woźniak, A. (2012, 26 września). Polska wysoko w rankingu atrakcyjności przejęć. Rzeczpospolita.

Wybranowski, W. (2011, 23 listopada). Walczą o wolność gospodarczą. Rzeczpospolita.

Wybranowski W. (2012, 17 lutego). Przedsiębiorcy bez ochrony. Rzeczpospolita.

Wybranowski, W. (2012, 23 lipca). Siedem lat gehenny przedsiębiorców. Rzeczpospolita.

Wybranowski, W. (2013, 9 marca). Zabójczy ciężar podatku. Rzeczpospolita.

Zioło, Z. (1988). Funkcjonowanie i rozwój przedsiębiorstwa przemysłowego w przestrzeni geograficznej.

W: Z. Zioło (red.). Zakład przemysłowy w akademickim kształceniu nauczycieli geografi, Materiały i sprawozdania nr 16, COMSN, WSP w Krakowie, Kraków: Wydawnictwo Naukowe WSP, 8-24.

Zioło, Z. (1994). Zmiana roli przestrzeni geograficznej w procesie transformacji systemu gospodarowania. W: Z. Zioło (red.). Zachowania przestrzenne przemysłu w zmieniajacych się warunkach gospodarowania, Komisja Geografii Przemysłu Polskiego Towarzystwa Geograficznego, 14-21.

Zioło, Z., Rachwał, T. (red.). (2008). Przedsiębiorczość w gospodarce opartej na wiedzy, Przedsiębiorczość-Edukacja, 4. 
Zioło, Z., Rachwał, T. (red.). (2009). Wpływ globalizacji i integracji europejskiej na transformację struktur przemysłowych, Prace Komisji Geografii Przemystu Polskiego Towarzystwa Geograficznego, 12.

Zioło, Z., Rachwał, T. (red.). (2010). Przedsiębiorczość w warunkach integracji europejskiej, Przedsiębiorczość - Edukacja, 6.

Zioło, Z., Rachwał, T. (red.). (2011a). Wpływ kryzysu na zachowania przedsiębiorstw oraz przemiany struktur regionalnych, Prace Komisji Geografii Przemystu Polskiego Towarzystwa Geograficznego, 17.

Zioło, Z., Rachwał, T. (red.). (2011b). Przedsiębiorczość w warunkach globalizacji, Przedsiębiorczość - Edukacja, 7.

Zbigniew Zioło, dr nauk przyrodniczych, dr hab. i prof. nauk ekonomicznych, Uniwersytet Pedagogiczny im. Komisji Edukacji Narodowej w Krakowie, Instytut Geografii, Zakład Przedsiębiorczości i Gospodarki Przestrzennej.

Zainteresowania badawcze: gospodarka przestrzenna, geografia ekonomiczna, polityka społeczno-gospodarcza, ekonomika i polityka rozwoju regionalnego.

Zbigniew Zioło, ScD, PhD, Prof of Economics. Pedagogical University of Cracow, Institute of Geography, Department of Entrepreneurship and Spatial Management.

Research interests: spatial management, economic geography, socio-economic policy, economics and policy of regional development.

Adres/Address: Uniwersytet Pedagogiczny w Krakowie, Instytut Geografii

Zakład Przedsiębiorczości i Gospodarki Przestrzennej

ul. Podchorążych 2, 30-084 Kraków, Polska

e-mail: ziolo@up.krakow.pl 